\title{
Mesenchymal stem cells and natural killer cells interaction mechanisms and potential clinical applications
}

\author{
Batol Abbasi ${ }^{1,2}$, Karim Shamsasenjan $^{1,3^{*}}$, Majid Ahmadi $^{4}$, Seyedeh Ameneh Beheshti ${ }^{1,2}$ and Mahshid Saleh ${ }^{5}$
}

\begin{abstract}
Natural killer cells (NK cells) are innate immune cells that are activated to fight tumor cells and virus-infected cells. NK cells also play an important role in the graft versus leukemia response. However, they can over-develop inflammatory reactions by secreting inflammatory cytokines and increasing Th1 differentiation, eventually leading to tissue damage. Today, researchers have attributed some autoimmune diseases and GVHD to NK cells. On the other hand, it has been shown that mesenchymal stem cells (MSCs) can modulate the activity of NK cells, while some researchers have shown that NK cells can cause MSCs to lysis. Therefore, we considered it is necessary to investigate the effect of these two cells and their signaling pathway in contact with each other, also their clinical applications.
\end{abstract}

Keywords: Natural killer cell, Mesenchymal stem cells, Immunomodulation, Signaling, Therapeutic

\section{Introduction}

Natural killer (NK) cells are a member of the body's innate immune system, which have anti-tumor and anti-viral roles [1]. NK cells in leukemia patients who are candidates for hematopoietic stem cell transplantation (HSCT) play an important role in the graft-versusleukemia (GVL) response [2]. Following HSCT, NK cells are the first population of lymphocytes that recover after HSCT, which helps improve transplantation, reduce rates of leukemia relapse, and reduce GVHD [3, 4]. However, some studies have shown that transplanted NK cells may lead to GVHD by producing pro-inflammatory cytokines (IFN- $\gamma, \mathrm{TNF}-\mathrm{a})$ that directly cause cell damage or indirectly by increasing the activity of transplanted $\mathrm{T}$ cells [3].

Mesenchymal stem cells (MSCs) are multipotent and non-hematopoietic stem cells that can differentiate into mesenchymal and non-mesenchymal tissues [5]. There

\footnotetext{
*Correspondence: shamsk@tbzmed.ac.ir

${ }^{1}$ Hematology and Oncology Research Center, Tabriz University of Medical Sciences, Tabriz, Iran
}

Full list of author information is available at the end of the article are many reports that MSCs can affect the immune system by interacting with myeloid and lymphoid cells [6]. It has recently been shown that they can inhibit activity B cells [7-9], T cells [8-11], NK cells [12], dendritic cells $[13,14]$, and macrophages [9] through direct cell-to-cell interaction and secretion of soluble factors including prostaglandin E2 (PGE2), indoleamine-2,3-dioxygenase (IDO), and transforming growth factor-beta (TGF- $\beta$ ) [15-18]. MSCs due to regulate the immune system can reduce GVHD in allogeneic HSCT $[19,20]$. They can escape the immune system by the lack or low expression levels of stimulatory molecules [21], and also they can survive for a long time in an allogeneic environment [22]. Therefore, their allogeneic cell products can be used for therapeutic applications to regulate the immune system in autoimmune diseases, transplantation, and tissue regeneration [23].

This review investigates how MSC could affect NK cell phenotype, proliferation, and activity. We also show signaling two cells in contact with each other and therapeutic applications of MSC on NK cell-related diseases. original author(s) and the source, provide a link to the Creative Commons licence, and indicate if changes were made. The images or other third party material in this article are included in the article's Creative Commons licence, unless indicated otherwise in a credit line to the material. If material is not included in the article's Creative Commons licence and your intended use is not permitted by statutory regulation or exceeds the permitted use, you will need to obtain permission directly from the copyright holder. To view a copy of this licence, visit http://creativecommons.org/licenses/by/4.0/. The Creative Commons Public Domain Dedication waiver (http://creativeco mmons.org/publicdomain/zero/1.0/) applies to the data made available in this article, unless otherwise stated in a credit line to the data. 


\section{Characterization of MSCs}

MSCs were identified over 50 years ago as a group of human and mammalian bone marrow cells that can be extracted and proliferated in vitro [24]. MSCs is obtained from various sources, including adipose tissue, bone marrow, skin [25], umbilical cord or peripheral blood, dental pulp, amniotic fluid, synovium, endometrium, dental pulp, heart [26], brain [27], umbilical cord tissue, and almost any graft tissue after delivery [28-31]. These cells have shown fibroblast-like appearance [32]. MSCs also characterized by other properties such as (a) adherence to plastic in culture; (b) differentiation into adipocytes, chondrocytes, and osteoblasts, under standard in vitro tissue culture-differentiating conditions; (c) expression of surface markers CD73, CD90, and CD105, and lack the expression of CD14, CD45, CD34, CD11b, CD19, CD79 $\alpha$, and HLA-DR in cells surface [31, 33-35]. It has shown that, depending on the tissue type, the panel of antigens may be different [6]. Table 1 shows cell surface markers of mesenchymal cells derived from different tissues [36, 37]. In the bone marrow, MSCs are essential in the development and maintenance of hematopoiesis by supplying many soluble factors such as growth factors and cytokines besides. MSCs directly interact with neighboring cells such as HSCs and extracellular matrix through adhesion molecules and extracellular matrix proteins such as integrins, ICAMs, and selectins [6].

MSCs modulate the immune system. They also have some properties of repairing damaged tissue [38]. MSCs are moved to the various tissues by chemokines released from damaged tissue and begun tissue regeneration by differentiating into organ-specific mature cells. They move from the bloodstream to damaged tissue by rolling on the endothelium, adhesion, trans-endothelial migration, extravasation [6]. Recent findings indicate that the pericyte population in the vessel might be a source of MSCs $[39,40]$. Pericytes are cells that surround endothelial cells in capillaries and small plates in different organs and are essential in stabilizing blood vessels. The observation that led them to this conclusion is that cells with MSC markers also express pericyte markers. This relationship is further demonstrated by cell sorting for pericytes (CD34-, CD56-, CD45-, CD146+) and subsequent expanded into cells of multiple lineages in vitro (chondrogenic, osteogenic, adipogenic, and myogenic). Also, the expression of MSC markers by pericytes indicates that pericytes may be able to form various lines as a reservoir of precursor cells $[40,41]$. In recent studies, adventitial cells (the cells that cover the outermost layer of all blood vessels except capillaries) are considered as MSCs precursors. Therefore, it can be concluded that both pericyte and adventitial cells can be precursors to MSC [42].

\section{Characterization of NK cell}

NK cells are present in many parts of the body, including the spleen, thymus, lymph nodes, bone marrow (BM), peripheral blood (PB), uterus, and liver [43]. They can detect dying tumor cells and virus-infected cells without prior activation. They can also distinguish between normal and transformed cells by major histocompatibility complex (MHC) class I molecule expressed on cells.

Table 1 Mesenchymal stem cells markers from various tissues

\begin{tabular}{|c|c|c|c|c|c|c|}
\hline & BM-MSC & AT-MSC & FB-MSC & PB-MSC & CB-MSC & PLA-MSC \\
\hline Positive & $\begin{array}{l}\text { CD9, CD13, CD29, } \\
\text { CD44, CD51, CD58, } \\
\text { CD59, CD61, CD62L, } \\
\text { CD73, CD90, CD104, } \\
\text { CD105, CD106, } \\
\text { CD119, CD120a, } \\
\text { CD120b, CD121a, } \\
\text { CD124, CD126, } \\
\text { CD127, CD140a, } \\
\text { CD140b, CD146, } \\
\text { CD166, CD271, } \\
\text { CD340, CD349 }\end{array}$ & $\begin{array}{l}\text { CD44, CD90, CD105, } \\
\text { CD106, CD146, } \\
\text { CD166, CD9, CD13, } \\
\text { CD29, CD54, CD73, } \\
\text { HLA I, STRO-1 }\end{array}$ & $\begin{array}{l}\text { CD29, CD44, CD73, } \\
\text { CD105 }\end{array}$ & CD90, CD105, CD133 & $\begin{array}{l}\text { CD13, CD29, CD44, } \\
\text { CD73, CD90, CD95, } \\
\text { CD105, CD106, } \\
\text { CD133, CD166 }\end{array}$ & $\begin{array}{l}\text { CD9, CD13, CD44, } \\
\text { CD63, CD73, CD90, } \\
\text { CD105, CD271, CD349 }\end{array}$ \\
\hline Negative & $\begin{array}{l}\text { CD1a, CD3, CD4, } \\
\text { CD5, CD11a, CD14, } \\
\text { CD15, CD18, CD25, } \\
\text { CD31, CD33, CD34, } \\
\text { CD38, CD45, CD50, } \\
\text { CD56, CD62E, CD62P, } \\
\text { CD71, CD123, CD133, } \\
\text { CD144, CD178 }\end{array}$ & $\begin{array}{l}\text { CD31, CD45, CD11b, } \\
\text { CD14, CD19, CD34, } \\
\text { CD79, CD133, CD144, } \\
\text { HLA-DR }\end{array}$ & $\begin{array}{l}\text { CD14, CD34, CD45, } \\
\text { CD68 }\end{array}$ & CD14, CD34, CD45 & $\begin{array}{l}\text { CD14, CD34, CD38, } \\
\text { CD45, CD71 }\end{array}$ & CD31, CD34, CD45 \\
\hline
\end{tabular}


Normal cells express MHC class I molecule. They can engage NK cell inhibitory receptors and are protected from NK cell-mediated lysis, while malignantly transformed cells via losing the MHC class I molecules activate NK activator receptors [44]. Besides, NK cells can improve the immune system's response to target cells by increase downstream immune responses and increasing both the quality and the strength of adaptive immune defenses [45, 46]. Cell-surface NK receptors (NKRs), which recognize MHC class I and class I-like molecules signal, inhibit, and activate NK cell function, thereby enabling NK cells to identify and selectively target foreign cells $[47,48]$. There are three significant superfamilies of NKRs in humans: (1) the killer cell Ig-like receptor (KIR), which primarily recognizes MHC class I molecules, (2) Ig-like transcripts (ILTs), (3) CD94-NKG2A heterodimer. These receptors are inhibitory [49]. In humans, subsets of NK cells express CD16 (FcyRIII), and also express CD56 [neural cell adhesion molecule (NCAM) or Leu19] in high level [50]. The researchers divided human NK cells into two subsets, CD56bright and CD56dim NK cells, each with distinct phenotypes and different roles in immune responses. Approximately $90 \%$ of human NK cells are composed of CD56dim CD16bright NK cells, which are responsible for antibody-dependent cellular cytotoxicity (ADCC) through the high expression of CD16 and low expression of CD56. In comparison, about $10 \%$ of peripheral blood NK cells are CD56bright CD16dim/neg cells. Therefore, it can be said that CD56dim cells are more cytotoxic than CD56bright cells $[49,51]$. Recent studies have shown that CD56bright NK cells produce high cytokines, especially Interferon gamma (IFN- $\gamma$ ), while CD56dim NK cells produce low levels of cytokines. Each of these subsets has a different expression of NKRs, home molecules, and cytokine receptors. For example, CD56bright NK cells express low levels of killer immunoglobulin-like receptors (KIRs) but high levels of the inhibitory CD94/NKG2A NKR. They also express the high-affinity interleukin-2 (IL-2) receptor (IL-2R), which enables them to respond to low doses of IL- 2 and produce IFN- $\gamma$; and also express homing molecules CXCR3, L-selectin, and CCR7. By contrast, the CD56dim NK indicates a wide range of inhibitory NKRs, including KIR, and has low-affinity IL-2R, lacks CCR7, and low expression of $\mathrm{L}$-selectin. Since CD56bright NK cells express high levels of IL-2R and T cells and DCs are the only cells that produce IL-2, it suggests these cells have cytokine interactions in vivo [51].

\section{MSC effect on NK cells}

\section{Effect on the proliferation of NK cells}

Several studies have shown that MSCs inhibit the proliferation of activated NK cells. In these studies, researchers investigated the inhibitory effect of MSC on NK cell proliferation with various sources of MSC, including, bone marrow-derived mesenchymal stem cells (BM-MSCs) [52, 53], adipose tissue-derived mesenchymal stem cells (AT-MSCs) [54], Wharton's Jelly-derived mesenchymal stem cells (WJ-MSCs) [55], foreskin-derived mesenchymal stem cells (FSK-MSCs) [56]. NK cell proliferation is differentially regulated and modulated by MSCs depending on NK cell-activating cytokines. When NK cells stimulated with IL-2 [53-57], IL-12 [53-56], IL-15 [52-57], IL-21 [53-56], the presence of MSCs significantly but different extents inhibited NK cell proliferation. Spaggiari et al. [57] investigated the effect of BM-MSC on inactivated and IL-15-activated NK cells proliferation. They showed that BM-MSCs inhibited the proliferation of resting NK cells and occurred at all NK/MSC ratios tested. While BM-MSCs only partial inhibition on the proliferation of IL-15-activated NK cells and are dependent on the NK/MSC ratio. Pradier et al. [52] also showed that the proliferation of IL-15-activated NK cells is strongly inhibited by BM-MSCs. They attributed the inhibition of NK cell proliferation to BM-MSC-secreted IDO. Najar et al. [53] showed the proliferation of NK cells activated with IL-12- and IL-21 was significantly reduced by BMMSCs, while the proliferation of IL-2 and IL-15-activated NK cells slightly decreases in the presence of BM-MSCs. They observed a slight decrease in the proliferation of IL-2-, IL-12-, IL-15- and IL-21-activated NK cells in the presence of AT-MSCs [54]. They also showed that WJMSCs and FSK-MSCs were significantly inhibited NK cell proliferation activated with IL-2, IL-12, IL-15, and IL-21 [55, 56]. Panagiota et al. [58] showed that factors secreted by BM-MSCs suppress NK cell proliferation, as reported for T cells. Gieseke et al. [59] investigated the effect of MSC-derived galectin-1 on the proliferation of immune effector cells. Galectin-1 is a protein that is present intracellularly and on the cell surface of MSCs. This protein is also secreted by MSCs. They have shown that BM-MSC-derived galectin-1 inhibits CD4+ and CD8+ $\mathrm{T}$ cells proliferation. They also investigated the effect of MSC-derived galactin-1 on the suppression of NK cell proliferation. For this purpose, NK cells were isolated using MACS technology, then stimulated with IL-2, and eventually cultured with BM-MSCs of knockdown galectin-1. They observed that galectin-1 knockdown in MSCs had no effect on inhibition of NK cell proliferation by MSC.

\section{Effect on apoptosis rate of NK cells}

MSCs induce apoptosis into allogeneic NK cells. To determine the induction of apoptosis by MSC, $\mathrm{Li}$ et al. [60] exposed NK cells to BM-MSC cells in both transwell and mixed co-culture methods. They examined the cell 
cycle distribution of NK cells cultured with BM-MSC using flow cytometry analysis. In this analysis, the DNA fragment analysis reflects endonuclease activity in the process of apoptosis. Cells in the pre-G 0/G 1 stage (M4) were designated as apoptotic cells. They observed that in both the transwell and mixed co-culture groups, the percentage of cells in the G0/G1 phase was higher than that in the control group, whereas the rate of cells in $\mathrm{S}$ and G2/M phases was lower. They showed that MSC inhibits the NK cell cycle in the G0/G1 phase. The results showed that the apoptosis rate of NK cells significantly increased in both transwell and mixed co-culture groups. Besides, they established the rate of NK cell apoptosis in transwell groups was considerably higher than mixed co-culture groups. These results indicate that MSCs can affect NK cell apoptosis through soluble factors.

\section{Effect on cytokine production of NK cells}

NK cells produce a variety of inflammatory cytokines, including IFN- $\gamma$, after active by activating receptors [50]. NK cells directly induce anti-tumor activity by secreting pro-inflammatory cytokines and chemokines such as IFN- $\gamma$, tumor necrosis factor alpha (TNF- $\alpha$ ), interleukin-6 (IL-6), granulocyte-macrophage colony-stimulating factor (GM-CSF), and chemokine ( $\mathrm{C}-\mathrm{C}$ motif) ligand 5 (CCL5) and also promote innate and adaptive responses [61]. Many articles have discussed the effect of MSCs on the rate of cytokine secretion by NK cells. In most of these studies, to investigate this effect, NK cells cultured with MSC cells were considered as a positive control, and NK cells cultured in the absence of MSC as a negative control. In these trials, different results were obtained. Some studies point to increased production and secretion of inflammatory cytokines in NK cells cocultured with MSC, but others show a decrease in the inflammatory cytokines rate. Grazia Maria Spaggiari et al. analyzed whether MSC induces IFN- $\gamma$ production in NK cells, incubate NK cells at different NK/MSC ratios of autologous or allogeneic BM-MSC in the presence of the monensin-containing GolgiStop. They found that NK cells produced IFN- $\gamma$ in the presence of MSC [57]. DelaRosa et al. [62] compared IFN- $\gamma$ production in NK cells in their co-cultures with two hASCs and hBM-MSCs separately. They observed an increase in IFN- $\gamma$ production when they used hASCs or hBM-MSCs as target cells. But there was no significant difference between hASCs and hBM-MSCs. Hu et al. [63] investigated the production of IFN- $\gamma$ by NK cells after direct and indirect co-culture with BM-MSC. They observed that IFN- $\gamma$ secretion was increased (over three folds) in the co-culture directly but was not affected by the transwell method, indicating that a contact-dependent mechanism is involved.
IL-2-activated NK cells constitutively produced much more IFN- $\gamma$ than TNF- $\alpha$. Upon co-culture with ATMSCs, the levels of both IFN- $\gamma$ and TNF- $\alpha$ increased. The level of IFN- $\gamma$ produced by IL-2-activated NK cells considerably increased, whereas the level of TNF- $\alpha$ was slightly raised [54-56]. In this experiment, they used different sources of MSC, FSK-MSCs [56], WJ-MSCs [55], AT-MSCs [54], and BM-MSCs [53] for co-culture with NK cell. They all observed a similar effect on cytokine production and secretion by IL-2-activated NK cells. Several other articles have seen a decrease in the production and secretion of IFN- $\gamma$ and TNF- $\alpha$. Debanjana Chatterjee et al. cultured IL-18 and IL-12 pre-stimulated NK cells with or without human umbilical cord derived- MSC (UC-MSC). They find out that IFN- $\gamma$ production in NK cells co-cultured with UC-MSC cells compared to cultured NK cells alone decrease considerably. These findings indicate that UC-MSCs cause NK cells to respond less to stimulations by IL-12 or IL-18 or the combination of the two. They attributed this reduction in NK cells' response to IL-12 and IL-18 to a decrease in signaling IL-12R and IL-18R receptors. They stated that UCMSCs in co-cultured with NK cells had no effect on the expression rate of IL-12R and IL-18R receptors, while they decreased signaling of these receptors by a decrease in phosphorylation pSTAT4 at receptor IL-12R receptor and NF-kB at IL-18R receptor. Moreover, they also attributed the downregulation of IFN- $\gamma$ production in NK cells to activin-A produced by UC-MSCs by reducing T-bet levels in NK cells. A T-bet transcription factor is a significant modulator of IFN- $\gamma$ production in NK cells and $\mathrm{T}$ cells. The addition of Activin-A to the NK cell culture medium could substantially decrease IFN- $\gamma$ production level in response to IL-12/IL-18. On the other hand, MSCs produce Activin-A constructively that Activin-A secretion increased from MSCs when exposed to NK [64].

In addition to affecting the production and secretion of IFN- $\gamma$ and TNF- $\alpha$ [65], MSCs also effect on IL-10 and IL-6. Liu et al. [66] showed a decreasing effect on the production and secretion of IL- 6 , IFN- $\gamma$, and TNF- $\alpha$ and an increased effect on IL-10 by NK cells co-cultured with MSCs, whereas, Ma Qingqing et al. by evaluating the impact of BM-MSC on NK cells, found that BM-MSCs reduced TNF- $\alpha$ and IFN- $\gamma$ secretion from NK cells, while they had no effect on IL-10 [67]. Two other studies have also shown that BM-MSCs and AT-MSCs suppress the production and secretion of IL-10 from NK cells $[58,68]$.

\section{Effect on degranulation of NK cells}

The NK cells cytolytic function is accomplished through various processes death receptor binding or degranulation. They are vital for the scavenging of diseased and 
disordered cells [50]. CD107a is a marker of T-cell CD8+ and NK cell degranulation [69]. Since these membrane proteins appear on the cell surface after exocytosis of cytotoxic granules (CGs), it is hypothesized that some of these proteins may involve in the temporarily keeping of cytotoxic lymphocytes from self-degraded [70]. Several studies have reported the effect of MSC on NK cells degranulation by measuring CD107a expression during 5 days of NK cell co-cultured with MSC. They observed that the percentage of CD107a-expressing NK cells continuously increased until day 5 , but this increase was sustained in the presence of MSCs during period continuously and time-dependent. In this experiment, they used different sources of MSC, FSK-MSCs [56], WJ-MSCs [55], AT-MSCs [54], and BM-MSCs [53] for co-culture with NK cell. They all observed a similar effect on NK cells degranulation, whereas DelaRosa et al. [62] compared the sensitivity of hASCs and hBMMSCs to NK cell-mediated lysis by degranulation assays by finding CD107a/b at the surface molecule. Since the degranulation is associated with NK cell cytotoxicity, first NK cells stimulated by rhIL-2 to increase their cytotoxicity, then both hASCs and hBM-MSCs cells used as target cells. The results showed that the degranulation rate in response to hASCs was meager and not statistically significant. In contrast, hBM-MSCs induced a significantly increase in the NK cell degranulation response. To exclude the inhibitory effect of HLA class I, they blocked HLA class I in target cells by pretreating target cells with monoclonal antibody W6/32 before co-culture. The results showed that HLA class I coated by antibody did not increase the degranulation of NK cells against hASCs. Bruno et al. [71] did the same experiment with this difference that NK cells were stimulated by IL-15 rather than by rhIL- 2 to increase their cytotoxicity potential and also used human liver stem cells (HLSCs) and BM-MSCs cells as target cells. They observe MSCs induced degranulation in NK cells, whereas degranulation is absent in NK cells in response to HLSCs.

\section{Effect on cytotoxicity of NK cells}

Cytotoxic T lymphocytes (CTLs) and natural killer (NK) cells are effective lymphocytes that use common cytotoxic pathways to defend against cancer cells and virusinfected cells. Both types of cells destroy their cellular targets using both mechanisms that require direct contact between the effective and the target cells [72]. In the first pathway, they release the contents of their granules, including perforin (responsible for the formation of pores in the cell membranes of the target cells) [62] and of the granzymes (family of serine proteases that do a series of proteolytic events) [70] and lead to the death of the target cell. The second pathway involves the involvement and accumulation of target-cell death receptors like FAS (CD95), by their homogeneous ligands, such as FASL ligands (FASL), on the killer-cell membrane, that leads to classical caspase-dependent apoptosis [73]. This pathway destroys self-reactive lymphoid cells [74]. Several studies have shown that IL-2-activated NK cells constitutively release significant perforin and granzyme that granzyme A greater secretion rate than granzyme $B$. They stated that the secretion rate of both perforin and granzyme increased in the presence of MSCs [54-56]. In this experiment, they used different sources of MSC, FSK-MSCs [56], WJ-MSCs [55], AT-MSCs [54], and BM-MSCs [53] for co-culture with NK cell. They all observed a similar effect on the cytotoxic activity of NK cells, while Fu et al. showed that NK cell perforin secretion decreased after co-culture with decidua MSC (DMSC) [75]. Also many studies have shown that the cytotoxicity of NK cells suppressed by MSCs $[23,32,52,63,68,76]$. Chatterjee et al. [4] stated that UC-MSCs reduce the cytotoxic activity of NK cells through a decrease in the expression of NK cell surface receptors that are essential for their activity, not by altering the contents of the perforin and granzyme.

\section{Effect on expression receptors of NK cell}

NK cells have two groups of receptors called inhibitory and activating receptors on their surface that their activity controlled by these receptors [77]. These receptors have their ligands that can activate or inhibit NK cells [78]. Table 2 summarizes these activation and inhibitory receptors and other markers [79-82].

\section{Activating receptors}

When NK cells are activated, the expression of activating receptors on their surface increases, but in the presence of MSC, the expression of these receptors decreases [76, 83, 84]. In several studies, NK cells stimulated by IL-2, IL-12, IL-15, and IL-21 and measured the number of CD226 (DNAM-1), CD314 (NKG2D), CD335 (NKp46), CD336 (NKp44), and CD337 (NKp30) expressed on their surface. They observed that after the activation of NK cells by these cytokines, the rate of expression of activating receptors on their level increased, but in co-culture with MSC cells, the quality of expression of activating receptors decreased [53-56]. In this experiment, they used different sources of FSK-MSCs [56], WJ-MSCs [55], AT-MSCs [54], and BM-MSCs [53] for co-culture with NK cell. They all observed a similar effect on the expression of activating receptors NK cells. Spaggiari et al. [85] examined the rate of NKp30, NKG2D, NKp44, NKp46, CD69, 2B4 (CD244), IL-2R-8 chain (CD132), and CD16 expression on the surface of NK cells after activation with IL-2 and after co-culture with BM-MSC. They showed that the expression of activating receptors, including 
Table 2 Human NK cell markers and receptors

\begin{tabular}{|c|c|}
\hline & Ligands \\
\hline \multicolumn{2}{|l|}{ Activating receptors } \\
\hline CD94/NKG2C & HLA-E \\
\hline KIR2DL4 (CD158d) & $\mathrm{HLA}-\mathrm{G}, \mathrm{HS}$ \\
\hline KIR2DS1 (CD158h) & $\mathrm{HLA}-\mathrm{C}$ \\
\hline KIR2DS2/3 (CD158j) & HLA-C \\
\hline KIR2DS4 (CD158i) & HLA-A, C \\
\hline KIR2DS5 (CD158f) & ???? \\
\hline KIR3DS1 (CD158e2) & HLA-B \\
\hline 2B4 (CD244) & CD48 \\
\hline FCyRIII (CD16) & $\lg G$ \\
\hline NKp46 (335) & Viral antigens \\
\hline NKp44 (336) & Viral antigens \\
\hline NKp30 (337) & $\mathrm{B} 7-\mathrm{H} 6$ \\
\hline NKG2D (CD314) & MIC-A, MIC-B, ULBPS \\
\hline DNAM-1 (CD226) & Nectin-2 (CD112) PVR (CD155) \\
\hline NKp80 & AICL (activation-induced C-type lectin) \\
\hline NKRP-1 (CD161) & LLT-1 \\
\hline \multicolumn{2}{|l|}{ Inhibitory receptors } \\
\hline NKG2A/CD94 & HLA-E \\
\hline KIR2DL1 (CD158a) & HLA-C2 \\
\hline KIR2DL2/3 (CD158b) & HLA-C1 \\
\hline KIR2DL4 (CD158d) & $H L A-G$ \\
\hline KIR2DL5 (CD158f) & ???? \\
\hline KIR3DL1 (CD158e1) & HLA-B \\
\hline KIR3DL2 (CD158k) & HLA-A \\
\hline LIR-1 & HLA-A, -G \\
\hline TIM-3 & GAL-9 \\
\hline CEACAM1 & CEACAM1/5 \\
\hline PD1 (CD279) & PD1L(CD274 or B7-H1) \\
\hline KLRG-1 & Cadherins \\
\hline TIGIT & PVR, PVRL2 \\
\hline Death receptors and ligands & Ligands \\
\hline $\begin{array}{l}\text { TRAIL (TNF-related apoptosis- } \\
\text { inducing ligand or CD253) }\end{array}$ & DR4 (TRAlL-R1), DR5(TRAIL-R2) \\
\hline Fas ligand (CD95L) & CD95 \\
\hline Fas or Apo1 (CD95) & CD95L \\
\hline CD40L (CD154) & CD40 \\
\hline \multicolumn{2}{|l|}{ Other antigens } \\
\hline TNFRSF7 (CD27) & CD70 \\
\hline LAMP-1 (CD107a) & - \\
\hline
\end{tabular}

NKp30 and NKG2D, on NK cells increased after activation with IL-2, and NKp44 receptor and the activation marker CD69 expressed, while they are not present in inactivated cells. After co-culture with BM-MSC, NKp30, NKp44, and NKG2D expression decreased, and surface density of NKp46 and CD69 no reduced, and surface expression of 2B4 and CD132 inhibited, but it did not affect CD16 molecules. While Petri et al. [86] stated that when human nasal mucosa-derived MSCs (nm-MSCs) stimulated by poly (I:C), they secrete TGF- $\beta$ and IL-6, which in co-culture nm-MSC with NK cell, these two compounds reduce the expression of CD16, and also Abumaree et al. [84] stated that in IL-2-activated NK cells and cultured with placental MSCs (pMSC) for $24 \mathrm{~h}$, NKp46 and, CD69 expression were reduced.

\section{Inhibitory receptors}

When NK cells activated, inhibitory receptors on their surface reduced, while their expression increased in coculture with MSC. Yan et al. [76] stated that CD158a and CD158b inhibitory receptors on NK cells are increased by co-culture with human bone marrow mesenchymal stem cells (BMMSCs) and dental pulp stem cells (DPSCs), while Spaggiari et al. [85] showed in co-culture of IL-2-activated NK cells with BM-MSC no changes were observed in the expression KIRs and CD94/NKG2A receptors, and also Abumaree et al. [84] observed a decrease in CD94 expression on IL-2-activated NK cells after co-culture with pMSC.

\section{Effect on expression other markers of NK cell}

There are many markers on the surface of NK cells. They play an essential role in NK cell activity. In the interaction of NK cells with MSC, MSC changes these markers' expression on the surface of NK cells. Yan et al. [76] stated that the percentage of CD73 NK cells in peripheral blood is low, but in the interaction of NK cells with BMMSCs and DPSCs, the expression of CD73 on NK cells increases that these CD73-positive NK cells can regulate the NK cells function in autocrine and paracrine process. Previous studies have shown that NK cells have CD25 (IL-2R) and CD69 activation receptors on the self-surface that proliferation potential is shown by CD25. At the same time, CD69 is a specific marker for the cytotoxic activity of NK cells [87]. Li et al. [60] stated that the expression of CD69 in NK cells decreases after co-culture with BM-MSC that this reduction is more evident at higher MSC concentrations the higher. This decrease in CD69 expression can be a factor in reducing the cytotoxic activity of NK cells. MSC also affects the expression of other markers on the surface of the NK cell. For example, in NK cells cultured with pMSC in (25:1, 50:1, and 100:1) ratios after $24 \mathrm{~h}$, IL-18R $\beta$ expression increased in all ratios and IL-12R $\beta 1$, IFN- $y$ R1, and TLR3 expression increased in the ratio 25:1, while IL-12 $R \beta 1$ expression decreased in the ratios 50:1 and 100:1 and IFN-y R2 expression decreased in all ratios, but there was no change in the expression IL-18 R $\alpha$, TNF- $\alpha$, TLR7, and TLR9 [84]. Petri et al. [86] also showed that when $\mathrm{nm}$-MSCs stimulated by poly(I:C) and secretes TGF- $\beta$ and IL-6, cause increases CXCR4 expression on NK cell. 
They attributed the increase in expression of CXCR4 on NK cells to TGF- $\beta$ and stated that IL- 6 has an increasing effect on TGF- $\beta$ function.

\section{Effect on the phenotype of NK cell}

As mentioned earlier, one of the markers present on the NK cell surface and affects its phenotype is CD56. Based on the expression rate of CD56, NK cells are divided into two categories, CD56dim, and CD56bright. When NK cells are stimulated with IL-15 or IL-2 in vitro, CD56bright cells have a higher proliferation than CD56dim cells. In contrast, CD56dim cells have a relatively low expansion, so after 4 days they are exposed to IL-15 or IL-2, NK-cell cultures consist mainly of CD56bright cells [58, 88]. Sotiropoulou et al. [58] cultured NK cells with BM-MSC in both contact and transwell systems. They observed that CD56 expression was high in transwell systems as seen in NK cells in the absence of MSC, while decreased in the contact system. Also, the percentage of CD56bright cells decreased in the presence of MSC that was mainly contact-dependent [58, $68,88]$. They also stated that CD56 expression levels were lower in the CD56bright cells cultured contact with BMMSCs between groups, while in CD56dim cells, it was unchanged [58].

\section{NK cell effect on MSCs}

\section{Effect on the expression of MSC ligands}

To investigate the interactions between NK cells and MSCs, the researchers decided to analyze ligands expression of MSC surface recognized by NK cell-activating or inhibitory receptors. They identified surface ligands of MSCs using specific mAbs. Spaggiari et al. [57] showed the expression of MICA and ULBPs (both ligands of NKG2D), Nectin-2 and PVR (both ligands of DNAM-1), and low levels of HLA class I molecules among 15 populations of BM-MSC. However, none of the BM-MSCs were expressed CD48 (ligand 2B4) molecule. M. H. Abumaree et al. analyzed the expression rate of ligands of pMSCs and decidua parietalis derived-MSCs (DPM$\mathrm{SCs}$ ) surface related to NK cell-activating and inhibitory receptors by flow cytometry. They stated that the highest expression at the pMSCs surface, was ULBP-2 and the lowest expression was PVR. They also showed that 95.60 percentage of pMSCs expressed HLA-ABC and 30.93 percentage expressed HLA-E [84]. They also stated that DPMSCs expressed high levels of Nectin-2 and HLA$\mathrm{ABC}$ ligands and expressed low levels of MICA, MICB, ULBP-2, and HLA-E ligands [89]. DelaRosa et al. [62] compared ligands related to NK cell-activating or inhibitory receptors on the surface of both hBM-MSCs and hASCs. They showed that the expression of the HLA class I molecule and Nectin-2 and PVR ligands were higher in hBM-MSCs than hASCs, and the CD48 molecule was not expressed in both cells. They also stated that the expression of ULBPs and MICA / B ligands in hASC is negative or very low. They then examined the expression rate of ligands in inflammatory conditions. For this purpose, hASCs and hBM-MSCs were stimulated with IFN- $\gamma$ for $72 \mathrm{~h}$, and then the expression of ligands was evaluated. They showed expression of CD48, MICA/B, Nectin-2, and PVR did not increase significantly, while the expression of HLA class I and II molecules increased after $72 \mathrm{~h}$.

Mehdi Najar et al. investigated the expression rate of MSC ligands from various tissues after co-culture with un-activated and activated NK cells. For this purpose, NK cells are first activated by IL-2, IL-12, IL-15, and IL-21 and then co-culture with MSCs. They stated that in BMMSCs, the expression of Nectin-2 and PVR did not show any significant change after co-culture with inactivated or IL-21-activated NK cells, while in the presence of IL12 -activated NK cells showed a slight decrease and in the presence of IL-2- and IL-15-activated NK cells showed a more significant reduction [53]. In the case of AT-MSCs, the expression of Nectin-2 and PVR did not show any significant change against IL-12- and IL-21-activated NK cells, while showed a striking reduction in the presence of IL-2- or IL-15-activated NK cells [54]. They also stated that the expression of these two ligands remained unchanged at WJ-MSCs surface in the co-culture with inactivated and IL-21- or IL-12-activated NK cells, but it had a slight but significant reduction in co-culture with IL-15 or IL-2-activated NK cells [55]. The expression rate of Nectin-2 and PVR ligands on the FSK-MSCs surface after co-culture with un-activated, IL-12- or IL-21-activated NK cells were slightly affected. While a minor decrease in these ligands expression by FSK-MSCs was seen in the presence of IL-2-activated NK cells, a significant reduction was seen in the presence of IL-15-activated NK cells [56]. No change in ULBP3 expression was observed in all tests and in all MSC sources [53-56].

\section{Effect on MSC lysis rate}

Many studies have shown that MSCs were lysed by activated NK cells, not freshly isolated. Mehdi Najar et al. showed that activated PBMCs by PHA/IL-2 killed MSCs isolated from different tissues (BM-MSCs, AT-MSCs, WJ-MSCs, and FSK-MSCs). To identify the cell subpopulation involved in the death of MSCs, MSCs from various tissues were cultured with PBMCs lacking CD14, CD56, or CD3 cell population separately. They showed that activated PBMCs and without CD3+ or CD14+ cell population could not affect MSCs viability. Therefore, it shows that neither of these two immune cells is responsible for the death of MSCs, while activated PBMCs without 
CD56+ cell populations were not able to kill MSCs. They concluded that NK cells are the leading cause of MSC death. They then showed that inactivated NK cells did not kill MSCs, while MSCs are lysed in the presence of activated NK cells with IL-2-, IL-12-, IL-15- or IL-21. In addition, they stated that the percentage of lysed MSCs by activated NK cells varies depending on the activating cytokine type [53-56]. Also, Panagiota et al. [58] investigated the effect of inactivated and IL-15-activated NK cells on BM-MSC, and Hoogduijn et al. [90] examined the effect of inactivated and L-2- and IL-15-activated NK cells on AT-MSC, and Spaggiari et al. [57] investigated the effect of inactivated and IL-12- activated NK cells on BM-MSC, and Abumaree et al. [84, 89] examined the effect of inactivated and IL-12-activated NK cells on pMSC and DPMSC. They also stated that inactivated NK cells could not lysis MSCs, while cytokine-activated NK cells killed MSCs. The death rate of MSCs by activated NK cells is dependent on the dose of NK cells and has increased with the increasing number of NK cells compared to MSC [90, 91]. The researchers examined whether there was a difference in the lysis of allogeneic and autologous MSCs. They found no difference between autologous and allogeneic MSCs in lysis by NK cells [57, 90].

To determine which receptor-ligand interactions causes lysing MSCs by NK cells, the researchers used the mAb-mediated blocking method in cytotoxicity assays. Spaggiari et al. [57] stated that mAb-mediated blocking NKG2D, NKp30, and DNAM-1 on BM-MSC surface resulted in the inhibition of kill. But the blocking of NKp46 resulted in low inhibition. However the masking of NKp44 did not play an important role. They also showed that BM-MSCs lysis did not increase with blocking the HLA class I and the CD94/NKG2A (HLA-E specific inhibitory receptor). Abumaree et al. [84] stated that mAb-mediated blocking NKp46, NKp44, NKG2D, NKp30, and DNAM did not inhibit the lysis of pMSCs by NK cells. They also showed that blocking CD94/NKG2A did not affect killing pMSC by NK cells, while mAb-mediated blockade of the activating receptor CD69 leads to inhibition of pMSCs lysis by NK cells. Abumaree et al. [89] performed the same test on the DPMSCs. They showed antibody-mediated masking of NKG2D, NKp30, and NKp44 significantly inhibited DPMSCs lysis by NK cells, while the blocking CD69 leads to moderate inhibition of NK cellmediated DPMSCs lysis. But the blocking NKp46 and DNAM-1 did not inhibit NK cell lysis of DPMSCs. They also showed that blocking CD94/NKG2A did not increase the killing of DPMSCs by NK cells. Several studies have attributed the increase in cytotoxicity of NK cells against MSCs to the decreased serpins expression of MSCs during co-culture with NK cells and the effect of granzyme on MSCs. As previously mentioned, NK cells exert their cytolytic activity on target cells through the secretion of granzyme. However, excessive activity of granzyme causes damage to tissue cells. MSCs can inhibit the granzyme cytotoxic effect of NK cells by expressing serpins, a family of protease inhibitors, and thus escape from lysis by NK cells [92]. Previous reports have shown that serpin B9 protects MSCs against activated NK cells-mediated granzyme-dependent killing [93]. Several studies have shown high expression of serpin B9 in MSCs isolated from various sources (WJ-MSCs [55], BM-MSCs [53], AT-MSCs [54], and FSK-MSCs [56]). On the other hand, Mangan et al. showed that serpin B9 is inactivated by reactive oxygen species (ROS) [94]. Mehdi Najar et al. investigated the expression of serpin B9 and ROS production in various sources of MSCs (WJMSCs, BM-MSCs, AT-MSCs, and FSK-MSCs) during co-culture with IL-2-activated NK cells. They showed increased ROS production, decreased serpin expression and increased lysis susceptibility in all MSCs during coculture with IL-2-activated NK cells [53-56]. However, the researchers showed that MSCs were protected from lysis by NK cells by increasing IFN- $\gamma$ during inflammatory responses. Spagiari et al. [57] in a study on BMMSC, and Giuliani et al. [95] in a study on fetal-MSC (FL-MSC) and embryonic-MSC (ES-MSC), investigated the effect of IFN- $\gamma$ on the protection of MSC against NK cells. They showed that IFN- $\gamma$ increased HLA class I and HLA-E molecules expression in MSCs and decreased lysis of MSCs by NK cells. To confirm this hypothesis, they blocked HLA-I and CD94/ NKG2A receptor by $\mathrm{mAb}$. They observed that the killing of IFN- $\gamma$-treated MSCs by NK cells increased, indicating their role in MSCs protection. Hoogduijn et al. [90] examined whether immunosuppressive drugs could protect MSCs lysis against NK cells. To do this, they added tacrolimus, rapamycin, or sotrastaurin to NK cells together with MSCs. They observed that none of the immunosuppressants could prevent the lysis of allogeneic or autologous MSCs by activated NK cells. They repeated the experiment by pre-incubating activated NK cells with immunosuppressants for $24 \mathrm{~h}$ and also before and during NK cell activation with IL-2 and IL-15. Therefore, NK cells were incubated with rapamycin, tacrolimus, or sotrastaurin for $24 \mathrm{~h}$ before activation and then cultured with IL-2 and IL-15 for 7 days in the presence of the same drugs. They observed that none of the immunosuppressants could protect MSCs from lysis against NK cells. 


\section{Mechanisms involved in inhibiting NK cell function by MSC \\ Role of soluble factors in the immunoregulatory activity of MSCs}

In several studies, the cytotoxic suppression of NK cells by MSCs attributed to enzymes cyclooxygenase (COX)-2 [4], and IDO [52, 63, 96] and also their metabolites, respectively, prostaglandin (PG)-E2 $[4,63,96]$ and kynurenine $[52,63]$ produced by MSCs. They found significant concentrations of L-kynurenine induced by the degradation of L-tryptophan by IDO [52] and PGE2 endproduct COX-2 [4] by PGE2 synthase [63] in the NK-activated MSC medium. They proved their theory by using antibodies blocking these enzymes and their metabolites. They also stated that initial cell contact between MSC and NK cells is required to induce the inhibitory effect through soluble factors synthesized by MSC. MSCs require preincubation with NK cells, and activation via IFN- $\gamma$ is derived from these cells [97]. They first cultured BM-MSCs with IL-15-activated NK cells. They observed a significant concentration of $\mathrm{L}-\mathrm{kynurenine}$ in the IFN- $\gamma-$ activated MSCs medium cultured with IL-15-stimulated NK cells, and then observed L-Kynurenine synthesis was inhibited by blocking anti-IFN- $\gamma$ mAb [52]. Also, Chatterjee et al. [98] stated that IL-1 $\beta$ produced by NK cells causes COX-2 upregulation in MSCs. They added IL-1 $\beta$ neutralizing antibody in NK-MSC co-cultures for confirming their hypothesis, which observed a significant inhibition of COX-2 upregulation. They also stated that the interaction between the two cells was dependent on cellular contact.

In one study, the effects of fetal liver (FL) MSC-derived exosomes (FL-exo) and MSCs derived from the human fetal liver (FL-MSC) on NK cells activity were investigated. They observed that FL-exo and FL-MSC impaired the activity of NK cells. They performed a proteome analysis by mass spectrometry to identify factors related to the inhibitory effects of exosomes. This analysis revealed the presence of TSP1, which is a latent TGF $\beta$ activator through the conformational change in the latency-associated peptide (LAP). They also showed surface expression of TSP1 on FL-exo by flow cytometry. Immunoprecipitation of LAP, a component of the latent TGF $\beta$ complex, showed the co-precipitation of TGF $\beta$ and TSP1, indicating the interaction of LAP with TGF $\beta$ and TSP1 on FLexo. They also examined whether the exosome induces the TGF $\beta /$ Smad pathway on the NK cell. They found that IL-2-activated NK cells did not exhibit Smad2/3 phosphorylation but after treatment with TGF $\beta$ or FL-exo induced Smad2/3 phosphorylation in NK cells, which concluded that the inhibitory effect of exosomes on NK cell function is dependent on surface expression of TGF $\beta$ on FL-exo. They used an anti-TGF $\beta$ neutralizing antibody to prove their theory. They observed that NK cells' activity was restored by these antibodies, thus suggesting that the inhibitory effect of FL-exo and FL-MSC on NK cells activity partially dependent on their TGF $\beta$ expression [23]. Eventually, MSCs inhibit the cytotoxic activity of NK cells by a decrease in exocytosis and decrease in perforin release by NK cells via release of these soluble factors [52].

\section{Role JAK/STAT cytokine signaling}

NK cells need JAK/STAT signaling in response to more than 50 cytokines, hormones and growth factors to the regulation of differentiation, survival, proliferation, migration, and cytotoxicity [99-101]. The JAK/STAT signaling cascade can transmit extracellular signals from the cell membrane to the nucleus through various stages. When cytokines bind to the corresponding receptor, receptor-related JAK kinases come into proximity, and resulting JAKs phosphorylate each other and also the intracellular part of the receptor, and several downstream signaling molecules, including STATs. STAT phosphorylation causes them to dimmer with other STATs and separate them from the membrane complex and migrate to the nucleus [102]. In the nucleus, STATs regulate gene expression and subsequently affect cell proliferation and activity [103]. JAK family have four members (JAK1-3 and TYK2) and STAT proteins are STAT1-4, STAT5A, STAT5B, and STAT6. Although individual members of the JAK/STAT cascade have a high homologation, their specific functions are significantly different. Each cytokine can capture other JAK and STATs in the JAK-STAT signaling pathway and affect the cell [102]. For example, by binding IL-10 to its receptor complex, phosphorylation of JAK1 and TYK2 proteins occurs, and eventually, STAT3 is phosphorylated, which suppresses the immune system [104], while suppressor of cytokine signaling (SOCS) family proteins can suppress the JAK kinases activity [105] and ultimately inhibit the action of the JAK/STAT signaling cascade [106] via competing with the STAT proteins for binding to the receptor [102]. In mammals, four family members (CISH, SOCS1, SOCS2, and SOCS3) are associated with the JAK-STAT pathway and inhibit this pathway [101]. Liu et al. [66] showed in co-culture mice MSC with mice NK cells, MSC affects the properties and function of NK cells by regulating the JAK-STAT signaling pathway and SOCS3, a downstream component of the JAK/STAT signaling pathway. They stated that IL-10 regulates NK cell activity through the JAK/STAT pathway. To prove their theory, they adding AG490 as a specific inhibitor of the JAK/ STAT pathway to the medium of NK cells cultured with MSC. They showed that the proliferation and expression 
of NK cell surface markers returned to normal levels before co-culture with MSCs.

\section{Role CD73 expressed on the level of NK cells in inhibiting their activity}

Ecto-5'-nucleotidase (CD73) and E-NTDPase (CD39) are ectoenzymes located on the membrane surface of immune cells, including T-cells, NK cells, B-cells, dendritic cells, and macrophages [107]. Purinergic (P1 and P2) signaling pathways play an essential role in regulating the immune system [108]. Adenosine (via P1) and ATP (via P2) are usually present in small amounts in extracellular fluids [109]. However, high levels of ATP are released in the cancer microenvironment due to cell destruction [110] that this extracellular ATP functions as a danger-associated molecular pattern (DAMP) and increases the immune response to cancer cells $[108,110]$. CD39 by converting ATP to AMP and CD73 by converting AMP to adenosine suppress the immune system [111]. As a result of the extracellular ADO accumulation, followed by the involvement of ADO receptors with $G$ protein (A1, A2A, A2B, and A3), the function of immune cells, including NK cells, is suppressed through various mechanisms [112] that tumor can use this mechanism to escape the immune system [113], while the loss of function of ADO production can cause autoimmune disorders (i.e., encephalomyelitis, multiple sclerosis, rheumatoid arthritis, diabetes, and uveitis) [114]. Yan et al. [76] stated that BMMSCs and DPSCs in co-culture with NK cells increase CD73 expression on NK cells, which suppresses NK cell function.

\section{Effect on LAIR pathway of NK cell}

The leukocyte-associated Ig-like receptor-1 (LAIR-1; CD305) is an ITIM-containing inhibitory immune receptor with a single immunoglobulin-like domain and a cytoplasmic tail, which is expressed on most blood leukocytes, including NK cells [115]. LAIR-1 is located on the surface of NK cells and activated when they bind to their ligands. They employ SHP-1 and SHP-2 phosphatases after activation, and leading to potent inhibition of NK cell toxicity [116]. One of the most essential LAIR1 -ligands is collagen $[75,117]$, which is abundant in the human body [118]. However leukocyte-associated Ig-like receptor-2 (LAIR-2; CD306) has homology with hLAIR1 , which can also be secreted. They lack a transmembrane and cytoplasmic area that competes with LAIR-1 to connect to the ligand $[75,119]$. Therefore, the LAIR-2 secretory receptor regulates the inhibitory potential of the membrane-bound hLAIR-1 through competition for the same ligands [75]. Najar et al. [55] investigated the effect of MSC from various sources on NK cell CD305 and CD306 expression after co-culture. They showed that unactivated NK cells and IL-2-activated NK cells express CD305 and CD306 on themselves, but in the co-culture of NK cells with MSC, their expression rate changes. They observed that when NK cells were co-cultured with WJ-MSC, the expression of both CD305 and CD306 markers decreased, while in co-culture with FSKMSC, increased the CD305 expression but, the CD306 expression remained unchanged [56]. They also showed that in the co-culture of NK cells with BM-MSC, CD305 expression remained unchanged, but CD306 expression decreased [53] and in co-culture with AT-MSC, expression of both markers remained unchanged [54]. The integrity of the triple collagen helix depends on the hydroxylation of proline by P4H. LAIR-1 possibly binds to the collagen triple helix peptides that contain several replications of glycine-proline-hydroxyproline [120]. Fu et al. [75] stated that decidua MSCs (DMSCs) can affect NK cell function by producing collagen and the interaction between collagen and LAIR-1. To prove this hypothesis, they disrupted collagen post-transcriptional modification by transfecting DMSCs with $\mathrm{P} 4 \mathrm{H}$ shRNA. They observed inadequate proline hydroxylation of collagen and eventually altered the ability of collagen to bind to LAIR-1.

\section{Mechanism of cell-to-cell contact between MSC and NK cells}

IL-15-, IL-2-, IL-21-stimulated NK cells can produce inflammatory cytokines, including IFN- $\gamma$, TNF- $\alpha[102$, $121]$, IL-1 $\beta$ [122] through the JAK-STAT signaling pathway. IFN- $\gamma$ and TNF- $\alpha$ affect MSC and increase COX-2 and IDO expression [123-125], IL-1 $\beta$ also increases COX-2 expression [125-127]. Finally, PGE2 produced by COX-2 $[128,129]$, and is kynurenine produced from tryptophan by IDO [130]. PGE2 released from the MSC through EP2 and EP4 that are NK cells receptors [131133] inhibits NKG2D expression [134, 135]. Also, activated adenylate cyclase in the PGE2 signaling pathway also increases the expression of the CD94/NKG2A inhibitory receptor on NK cells [136]. Kynurenine released by the MSC also inhibits NKG2D expression by NK cells $[134,137]$. In this way, PGE2 can decrease the production of IFN- $\gamma$ and TNF- $\alpha$ by NK cells $[129,132,138]$. MSC can also inhibit NK cell function by producing HLA-G, TGF$\beta$, IL-10, and HGF $[96,123]$. As previously mentioned, TGF- $\beta$ reduces NK cell proliferation [123] through the Smad2/3 pathway [23]. HGF also inhibits the function of NK cells by suppressing IFN- $\gamma$ and TNF- $\alpha$ expression [123]. HLA-G5 is an ILT2 inhibitory receptor-ligand on NK cells that inhibits NK cell function after binding to this receptor [139]. IL-10 also regulates NK cell function through the JAK/STAT signaling pathway [66] (Fig. 1). 


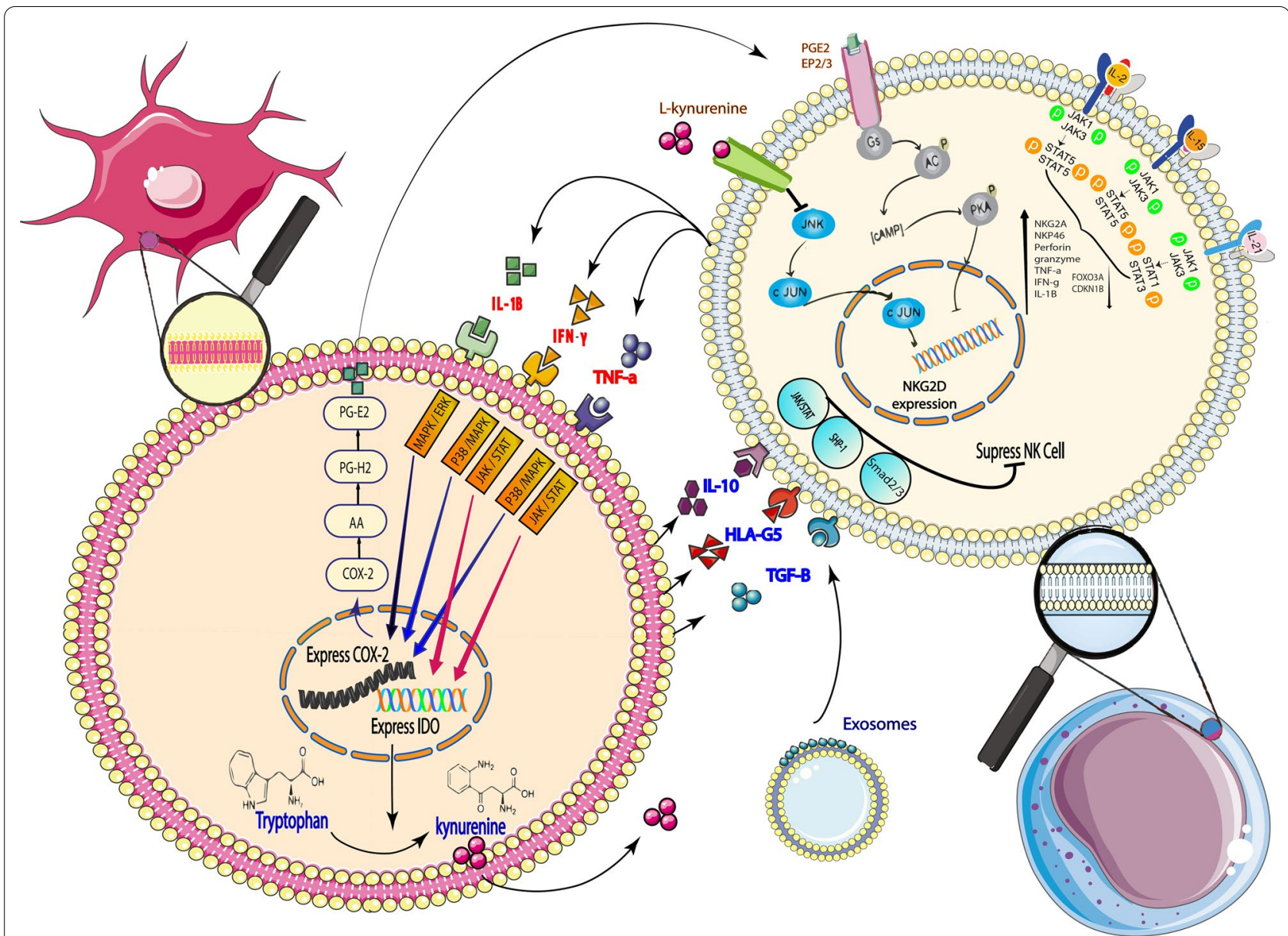

Fig. 1 Mechanism of cell-to-cell contact between MSC and NK cells. IL-15-, IL-2-, IL-21-stimulated NK cells release inflammatory cytokines. These inflammatory cytokines affect the MSC and caused the release of PGE2 and kynurenine and other factors from the MSC. The MSC inhibits the function of NK cells by these factors. PGE2 prostaglandin E2, IL-15 interleukin-15, IL-2 interleukin-2, IL-21 interleukin-21, COX-2 cyclooxygenase-2, IDO indoleamine-2,3-dioxygenase, AA acid arachidonic, $P G-H 2$ prostaglandin $\mathrm{H} 2$, IL-1 $\beta$ interleukin-1 $\beta$, IFN- $\gamma$ Interferon gamma, TNF- $\alpha$ Tumour Necrosis Factor alpha, EP2/3 Prostaglandin receptor, FOXO3AVCDKN1B quiescence-associated genes, IL-10 interleukin-10, HLA-G5 Human leukocyte antigen-G5, TGF- $\beta$ Transforming growth factor beta, STAT4 signal transducer and activator of transcription, JAK Janus kinase, NK cell natural killer cell

\section{The relationship between MSC-NK interactions with the incidence and therapy of diseases}

Association of MSC-NK interactions with malignancies

As mentioned earlier, MSCs can reduce the activity of NK cells. In one study, they compared the effect of MSC on NK receptors between two groups of MSC, nontumor tissue-derived MSCs (N-MSCs) and lung-tumorderived MSCs (T-MSCs). They found that T-MSCs reduces the expression of activating receptors of NK cells more than N-MSC [88]. T-MSCs also alter NK cell phenotype. They can increase the ratio of NKCD56dim: NKCD56bright cells. As we know, NKCD56bright cells are better producers of IFN- $\gamma$, while NKCD56dim cells have less protection against tumors that could be one of the reasons for tumor escape from the immune system and tumor progression [140]. On the other hand, the tumor environment contains tumor stromal cells (TSC), which have functional and morphological characteristics similar to MSCs and assumed MSCs may be the source of these stromal cells [141] and harm NK cells by reducing NKp44 and NKp46 expression [142]. Cytokine-activated NK cells are injected into cancer patients after HSC transplantation to eliminate the residual tumor cells [143]. Because the BM transplant contains small amounts of MSCs that survive for a long time in the host, they can have inhibitory effects on injected NK cells [144]. While some researchers, in addition to the suppressive effect of MSC on the immune system, observed the immune system's stimulating effects. Entrena et al. [145] used cells isolated from patients with acute lymphoblastic leukemia (ALL) in low-/moderate- and high-risk individuals to evaluate the suppressive or stimulating effect of MSC 
on the immune system. They observed that MSC isolated from low- and moderate-risk patients increased NK cell cytotoxicity, while MSC isolated from highrisk patients suppressed the anti-tumor function of NK cells. Therefore, they concluded that the effect of MSC on the immune system depends on the specific microenvironment of the tumor. For this reason, researchers are searching for MSC cells with the stimulatory properties of NK cells.

\section{Association of MSC-NK interactions with autoimmune diseases}

As mentioned earlier, excessive reactions of NK cells can cause a series of diseases. For example, NK cells can be a significant cause of virus-related asthma [146]. Also, in the peripheral blood of people with asthma, the activity of NK cells is increased [147], which migrates through the circulation toward lungs and lymphoid organs $[147,148]$. On the other hand, NK cells promote the response to the allergen through $\mathrm{T}$ cells $[149,150]$. Numerous studies have also shown an increase in the number and activity of NK cells in patients with multiple sclerosis (MS). They attack and damage myelinproducing oligodendrocytes [151-153]. NK cells found in the pancreas of patients with type 1 diabetes, while not seen in healthy people. Engagement of the NKP46 receptor of NK cells with pancreatic beta cells causes degranulation NK cells eventually cause disease [154]. In the synovial fluid of rheumatoid arthritis (RA) patients, an accumulation of NK cells was observed, which the researchers attributed the progression of the disease to the NK cells [155]. They also observed that patients' synovial fluid have more CD56bright NK cells secreting IFN- $\gamma$ than their peripheral blood [156], while in patients with systemic lupus erythematosus (SLE), there is a change in the ratio of CD56bright: CD56dim and an increase in the CD56bright subsets $[157,158]$. As mentioned previously, the cause of autoimmune diseases is an increase in the number or activity of NK cells. They can also differentiate activated Th cells into the Th1 lineage by secreting cytokines such as IFN- $\gamma$ and TNF- $\alpha$ and lead to more tissue damage [159].

In addition to its known properties, such as the ability to regenerate, MSC has some other exceptional properties that make them an excellent tool for use in medical science [160]. Today, MSCs are used to reduce various debilitating autoimmune disorders such as type 1 diabetes, SLE and MS [161]. One of the most essential benefits of MSC-based therapies is their ability to migrate preferentially to damaged tissues inflamed [162].
Association of MSC-NK interactions with organ transplants Recent studies have shown that in addition to $\mathrm{T}$ cells and B cells, NK cells play an essential role in innate and adaptive immune responses to the transplanted organ, and modulating their function may improve the transplant outcome [163]. NK cells can directly affect the transplanted organ through ADCC $[164,165]$ or by producing IFN- $\gamma$ and increasing Th1 [163], leading to transplant rejection. Cyclosporine is used to prevent liver transplant (LT) rejection; as an immunosuppressant, it reduces graft rejection [166]. However, suppressing the immune system causes unavoidable complications such as opportunistic infections, viral recurrence, and LT patients' metabolic complications [167]. Also, it is recently indicated that NK cell function is not inhibited by conventional immunosuppressive drugs [168]. For this reason, researchers are searching for alternative methods to modulate the function of NK cells. Many researchers have turned their attention to MSCs because of their immunomodulatory properties [169]. In addition to being used in the therapy of various diseases, MSCs are also used in transplantation due to their role in preventing allograft rejection. They prevent transplant rejection by inhibiting the function and detrimental effects of NK cells on the transplanted organ [170]. New studies on MSC have shown that MSC transplantation is used as a significant factor in regulating the immune system to prevent transplant rejection and GVHD [171]. Researchers investigated the effect of MSC on survival or rejection of kidney transplantation by examining pre- and posttransplant donor-directed MLR. They found MSCs, in addition to inhibiting CD4+ and CD8+ T cell lymphocyte proliferation, could also prevent NK cell proliferation [172]. Huang et al. [173] stated that MSC can reduce the number of filtered NK cells in ischemic hind limbs. Therefore, it can be concluded that MSC can reduce NK cells in ischemic transplant organs to regulate the immune system against transplantation [168]. The suppressive effect of MSC on the immune system induced under inflammatory conditions such as IFN- $\gamma$-rich microenvironments [168]. Researchers have concluded that when pre-activated MSCs are used instead of naive MSCs in the transplant, extended the survival time of the transplant in pancreatic islet grafts [174]. It has also shown that the use of dexamethasone (135) and azathioprine (128) during MSC transplantation can improve the function of transplanted MSC in modulating the immune system. 


\section{Conclusion}

Over the past few years, many researchers have focused on the moderating effect of MSC on the immune system. The researchers showed MSC modulate the function of immune system cells, including NK cells. Some studies have shown that MSC suppresses NK cell function, while a few studies show that MSC enhances NK cell function. This discrepancy in the effect of MSC on NK cells could depend on co-culture conditions such as incubation time, MSC:NK cell ratio, pre-stimulated NK cell conditions. However, most studies indicate that MSC suppresses NK cell function. Today due to the effect of MSC on NK cell function, it has been considered as a therapeutic tool for the therapy of many diseases, including autoimmune diseases, and prevents transplant rejection and GVHD.

\begin{abstract}
Abbreviations
NK: Natural killer; MSC: Mesenchymal stem cell; GVHD: Graft-versus-host disease; PGE2: Prostaglandin E2; IDO: Indoleamine-2,3-dioxygenase; COX-2: Cyclooxygenase-2; BM: Bone marrow; NKR: NK receptor; KIR: Immunoglobulinlike receptor; ILT: Immunoglobulin-like transcript; IL-2R: Interleukin-2 receptor; BM-MSC: Bone marrow-derived mesenchymal stem cell; AT-MSC: Adipose tissue-derived mesenchymal stem cell; WJ-MSC: Wharton's Jelly-derived mesenchymal stem cell; FSK-MSC: Foreskin-derived mesenchymal stem cell; LAIR1: Leukocyte-associated Ig-like receptor-1; LAIR-2: Leukocyte-associated lg-like receptor-2; FL-exo: Fetal liver MSC-derived exosomes; FL-MSC: Human fetal liver-derived mesenchymal stem cell; SOCS: Suppressor of cytokine signaling; IFN- $\gamma$ : Interferon- $\gamma$; TNF-a: Tumor necrosis factor-alpha; IL-1 $\beta$ : Interleukin-1 $\beta$; HGF: Hepatocyte growth factor; HLA-G: Human leukocyte antigen G.
\end{abstract}

\section{Acknowledgements}

This work has been done as part of the M.Sc. thesis for Batol Abbasi and supported by Hematology and Oncology Research Center, Tabriz University of Medical Sciences, Tabriz, Iran. B.A. wrote the manuscript. M. S. drew the schematic figure. S. B. wrote some parts of the manuscript. K. S. edited the final version and designed and supervised the study, whole correspondence during the paper submission.

\section{Authors' contributions}

BA wrote the manuscript. MS drew the schematic figure. SB wrote some parts of the manuscript. KSH edited the final version and designed and supervised the study, whole correspondence during the paper submission. All authors read and approved the final manuscript.

\section{Funding}

Hematology and Oncology Research Center, Tabriz University of Medical Sciences, Tabriz, Iran, Grant/Award Number: 62673.

\section{Availability of data and materials}

Not applicable.

\section{Declarations}

Ethics approval and consent to participate

Not applicable.

\section{Consent for publication}

Not applicable.

\section{Competing interests}

The authors declare no competing interests.

\section{Author details}

${ }^{1}$ Hematology and Oncology Research Center, Tabriz University of Medical Sciences, Tabriz, Iran. ${ }^{2}$ Student Research Committee, Tabriz University of Medical Sciences, Tabriz, Iran. ${ }^{3}$ Stem Cell and Regenerative Medicine Institute, Tabriz University of Medical Sciences, Tabriz, Iran. ${ }^{4}$ Stem Cell Research Center, Tabriz University of Medical Sciences, Tabriz, Iran. ${ }^{5}$ Department of Applied Cell Sciences, School of Advanced Technologies in Medicine, Tehran University of Medical Sciences, Tehran, Iran.

Received: 12 August 2021 Accepted: 9 October 2021

Published online: 07 March 2022

\section{References}

1. Sweeney EE, Balakrishnan PB, Powell AB, Bowen A, Sarabia I, Burga RA, Jones RB, Bosque A, Cruz CRY, Fernandes R. PLGA nanodepots coencapsulating prostratin and anti-CD25 enhance primary natural killer cell antiviral and antitumor function. Nano Res. 2020;13:736-44. https:// doi.org/10.1007/s12274-020-2684-1.

2. Ruggeri L, Mancusi A, Capanni M, Urbani E, Carotti A, Aloisi T, Stern M, Pende D, Perruccio K, Burchielli E, Topini F, Bianchi E, Aversa F, Martelli MF, Velardi A. Donor natural killer cell allorecognition of missing self in haploidentical hematopoietic transplantation for acute myeloid leukemia: challenging its predictive value. Blood. 2007;110:433-40. https:// doi.org/10.1182/blood-2006-07-038687.

3. Simonetta F, Alvarez M, Negrin RS. Natural killer cells in graft-versushost-disease after allogeneic hematopoietic cell transplantation. Front Immunol. 2017. https://doi.org/10.3389/fimmu.2017.00465.

4. Chatterjee D, Marquardt N, Tufa DM, Beauclair G, Low HZ, Hatlapatka T, Hass R, Kasper C, Von Kaisenberg C, Schmidt RE, Jacobs R. Role of gamma-secretase in human umbilical-cord derived mesenchymal stem cell mediated suppression of NK cell cytotoxicity. Cell Commun Signal. 2014;12:1-11. https://doi.org/10.1186/s12964-014-0063-9.

5. Pittenger MF, Mackay AM, Beck SC, Jaiswal RK, Douglas R, Mosca JD, Moorman MA, Simonetti DW, Craig S, Marshak DR. 10. C. Zener. Academic Press; 1987. http://science.sciencemag.org/.

6. Ns S, Na A. Sources of mesenchymal stromal cells: an overview. Am J Pharmacol. 2018;1:1-7.

7. Corcione A, Benvenuto F, Ferretti E, Giunti D, Cappiello V, Cazzanti F, Risso M, Gualandi F, Mancardi GL, Pistoia V, Uccelli A. Human mesenchymal stem cells modulate B-cell functions. Blood. 2006;107:367-72. https://doi.org/10.1182/blood-2005-07-2657.

8. English K. Mechanisms of mesenchymal stromal cell immunomodulation. Immunol Cell Biol. 2013;91:19-26. https://doi.org/10.1038/icb. 2012.56.

9. Gazdic M, Volarevic V, Arsenijevic N, Stojkovic M. Mesenchymal stem cells: a friend or foe in immune-mediated diseases. Stem Cell Rev Rep. 2015;11:280-7. https://doi.org/10.1007/s12015-014-9583-3.

10. Krampera M, Cosmi L, Angeli R, Pasini A, Liotta F, Andreini A, Santarlasci V, Mazzinghi B, Pizzolo G, Vinante F, Romagnani P, Maggi E, Romagnani S, Annunziato F. Role for interferon- $y$ in the immunomodulatory activity of human bone marrow mesenchymal stem cells. Stem Cells. 2006;24:386-98. https://doi.org/10.1634/stemcells.2005-0008.

11. Rasmusson I, Uhlin M, Le Blanc K, Levitsky V. Mesenchymal stem cells fail to trigger effector functions of cytotoxic T lymphocytes. J Leukoc Biol. 2007:82:887-93. https://doi.org/10.1189/jlb.0307140.

12. Aggarwal S, Pittenger MF. Human mesenchymal stem cells modulate allogeneic immune cell responses. Blood. 2005. https://doi.org/10. 1182/blood-2004-04.

13. Chen L, Zhang W, Yue H, Han Q, Chen B, Shi M, Li J, Li B, You S, Shi Y, Zhao RC. Effects of human mesenchymal stem cells on the differentiation of dendritic cells from CD34+ cells. Stem Cells Dev. 2007;16:719-31. https://doi.org/10.1089/scd.2007.0065.

14. Ramasamy R, Fazekasova H, Lam EWF, Soeiro I, Lombardi G, Dazzi F. Mesenchymal stem cells inhibit dendritic cell differentiation and function by preventing entry into the cell cycle. Transplantation. 2007:83:71-6. https://doi.org/10.1097/01.tp.0000244572.24780.54.

15. Castro-Manrreza ME, Montesinos JJ. Immunoregulation by mesenchymal stem cells: biological aspects and clinical applications. J Immunol Res. 2015. https://doi.org/10.1155/2015/394917. 
16. Tolar J, Le Blanc K, Keating A, Blazar BR. Concise review: hitting the right spot with mesenchymal stromal cells. Stem Cells. 2010;28:1446-55. https://doi.org/10.1002/stem.459.

17. Uccelli A, de Rosbo NK. The immunomodulatory function of mesenchymal stem cells: mode of action and pathways. Ann N Y Acad Sci. 2015;1351:114-26. https://doi.org/10.1111/nyas.12815.

18. Le Blanc K, Davies LC. Mesenchymal stromal cells and the innate immune response. Immunol Lett. 2015;168:140-6. https://doi.org/10. 1016/j.imlet.2015.05.004

19. Shirjang S, Mansoori B, Solali S, Hagh MF, Shamsasenjan K. Toll-like receptors as a key regulator of mesenchymal stem cell function: an upto-date review. Cell Immunol. 2017;315:1-10. https://doi.org/10.1016/j. cellimm.2016.12.005.

20. Tyndall A, Walker UA, Cope A, Dazzi F, De Bari C, Fibbe W, Guiducci S, Jones S, Jorgensen C, Le Blanc K, Luyten F, McGonagle D, Martin I, Bocelli-Tyndall C, Pennesi G, Pistoia V, Pitzalis C, Uccelli A, Wulffraat N, Feldmann M. Immunomodulatory properties of mesenchymal stem cells: a review based on an interdisciplinary meeting held at the Kennedy Institute of Rheumatology Division, London, UK, 31 October 2005. Arthritis Res Ther. 2007:9:301. https://doi.org/10.1186/ar2103.

21. Ankrum JA, Ong JF, Karp JM. Mesenchymal stem cells: immune evasive, not immune privileged. Nat Biotechnol. 2014;32:252-60. https://doi. org/10.1038/nbt.2816.

22. Svirshchevskaya EV, Poltavtsev AM, Os'mak GZ, Poltavtseva RA. Activation of NK cells in mixed cultures of Wharton's Jelly mesenchymal stromal cells and peripheral blood lymphocytes. Bull Exp Biol Med. 2018:164:339-43. https://doi.org/10.1007/s10517-018-3985-1.

23. Fan Y, Herr F, Vernochet A, Mennesson B, Oberlin E, Durrbach A. Human fetal liver mesenchymal stem cell-derived exosomes impair natural killer cell function. Stem Cells Dev. 2019;28:44-55. https://doi.org/10. 1089/scd.2018.0015

24. Caplan Al. Mesenchymal stem cells: Time to change the name! Stem Cells Transl Med. 2017:6:1445-51. https://doi.org/10.1002/sctm.17-0051.

25. Jeremias TDS, Machado RG, Visoni SBC, Pereima MJ, Leonardi DF, Trentin AG. Dermal substitutes support the growth of human skin-derived mesenchymal stromal cells: potential tool for skin regeneration. PLoS ONE. 2014. https://doi.org/10.1371/journal.pone.0089542.

26. Pilato CA, Stadiotti I, Maione AS, Saverio V, Catto V, Tundo F, Dello Russo A, Tondo C, Pompilio G, Casella M, Sommariva E. Isolation and characterization of cardiac mesenchymal stromal cells from endomyocardial bioptic samples of arrhythmogenic cardiomyopathy patients. J Vis Exp. 2018. https://doi.org/10.3791/57263.

27. da Silva Meirelles L, Chagastelles PC, Nardi NB. Mesenchymal stem cells reside in virtually all post-natal organs and tissues. J Cell Sci. 2006;119:2204-13. https://doi.org/10.1242/jcs.02932.

28. Fathi E, Valipour B, Sanaat Z, Charoudeh HN, Farahzadi R. Interleukin-6, -8 , and TGF- $\beta$ interleukin- $6,-8$, and TGF- $\beta$ secreted from mesenchyma stem cells show functional role in reduction of telomerase activity of leukemia cell via Wnt5a/ß-catenin and P53 pathways. Adv Pharm Bull. 2020;10:307-14. https://doi.org/10.34172/apb.2020.037.

29. Arutyunyan I, Elchaninov A, Makarov A, Fatkhudinov T. Umbilical cord as prospective source for mesenchymal stem cell-based therapy. Stem Cells Int. 2016. https://doi.org/10.1155/2016/6901286.

30. Bianco P, Robey PG, Simmons PJ. Mesenchymal stem cells: revisiting history, concepts, and assays. Cell Stem Cell. 2008;2:313-9. https://doi. org/10.1016/j.stem.2008.03.002.

31. Derakhshani M, Abbaszadeh H, Movassaghpour AA, Mehdizadeh A, Ebrahimi-Warkiani M, Yousefi M. Strategies for elevating hematopoietic stem cells expansion and engraftment capacity. Life Sci. 2019. https:// doi.org/10.1016/j.lfs.2019.116598.

32. Calkoen FGJ, Brinkman DMC, Vervat C, Van Ostaijen-Ten Dam MM, Ten Cate R, Van Tol MJD, Ball LM. Mesenchymal stromal cells isolated from children with systemic juvenile idiopathic arthritis suppress innate and adaptive immune responses. Cytotherapy. 2013;15:280-91. https://doi. org/10.1016/j.jcyt.2012.10.017.

33. Sarvar DP, Shamsasenjan K, Akbarzadehlaleh P. Mesenchymal stem cellderived exosomes: new opportunity in cell-free therapy. Adv Pharm Bull. 2016;6:293-9. https://doi.org/10.15171/apb.2016.041.

34. Dominici M, Le Blanc K, Mueller I, Slaper-Cortenbach I, Marini FC, Krause DS, Deans RJ, Keating A, Prockop DJ, Horwitz EM. Minimal criteria for defining multipotent mesenchymal stromal cells. The international society for cellular therapy position statement. Cytotherapy. 2006;8:315-7. https://doi.org/10.1080/14653240600855905.

35. Fathi E, Sanaat Z, Farahzadi R. Mesenchymal stem cells in acute myeloid leukemia: a focus on mechanisms involved and therapeutic concepts. Blood Res. 2019;54:165-74. https://doi.org/10.5045/br.2019.54.3.165.

36. Hass R, Kasper C, Böhm S, Jacobs R. Different populations and sources of human mesenchymal stem cells (MSC): a comparison of adult and neonatal tissue-derived MSC. Cell Commun Signal. 2011;9:12. https:// doi.org/10.1186/1478-811X-9-12.

37. Rojewski MT, Weber BM, Schrezenmeier H. Phenotypic characterization of mesenchymal stem cells from various tissues. Transfus Med Hemother. 2008;35:168-84. https://doi.org/10.1159/000129013.

38. Schepers K, Campbell TB, Passegué E. Normal and leukemic stem cell niches: insights and therapeutic opportunities. Cell Stem Cell. 2015;16:254-67. https://doi.org/10.1016/j.stem.2015.02.014.

39. Caplan Al. All MSCs are pericytes? Cell Stem Cell. 2008;3:229-30. https:// doi.org/10.1016/j.stem.2008.08.008.

40. Doherty MJ, Ashton BA, Walsh S, Beresford JN, Grant ME, Canfield AE. Vascular pericytes express osteogenic potential in vitro and in vivo. J Bone Miner Res. 1998;13:828-38. https://doi.org/10.1359/jbmr.1998. 13.5.828.

41. Caplan Al. Adult mesenchymal stem cells for tissue engineering versus regenerative medicine. J Cell Physiol. 2007;213:341-7. https://doi.org/ 10.1002/jcp.21200.

42. Corselli M, Chen CW, Sun B, Yap S, Rubin JP, Péault B. The tunica adventitia of human arteries and veins as a source of mesenchymal stem cells. Stem Cells Dev. 2012;21:1299-308. https://doi.org/10.1089/scd.2011. 0200

43. Del Zotto G, Marcenaro E, Vacca P, Sivori S, Pende D, Della Chiesa M, Moretta F, Ingegnere T, Mingari MC, Moretta A, Moretta L. Markers and function of human NK cells in normal and pathological conditions. Cytom Part B Clin Cytom. 2017;92:100-14. https://doi.org/10.1002/ cyto.b.21508.

44. Konjević G, Vuletić A, Martinović KM, Džodić R. The role of activating and inhibitory NK cell receptors in antitumor immune response. Nat Kill Cells. 2017. https://doi.org/10.5772/intechopen.69729.

45. Ferlazzo G, Tsang ML, Moretta L, Melioli G, Steinman RM, Münz C. Human dendritic cells activate resting natural killer (NK) cells and are recognized via the NKp30 receptor by activated NK cells. J Exp Med. 2002;195:343-51. https://doi.org/10.1084/jem.20011149.

46. Moretta A. Natural killer cells and dendritic cells: rendezvous in abused tissues. Nat Rev Immunol. 2002;2:957-64. https://doi.org/10.1038/ nri956.

47. Campbell KS, Colonna M. Human natural killer cell receptors and signal transduction. Int Rev Immunol. 2001;20:333-70. https://doi.org/10. 3109/08830180109054413.

48. Moretta A, Bottino C, Vitale M, Pende D, Cantoni C, Cristina M, Biassoni R, Moretta L. INvolved in HUman NAtural K Iller Cell-MEdiated CYtolysis. Biologia (Bratisl). 2001;7:197-223. https://doi.org/10.1146/annurev. immunol.19.1.197.

49. Cooper MA, Fehniger TA, Caligiuri MA. The biology of human natural killer-cell subsets. Trends Immunol. 2001;22:633-40. https://doi.org/10. 1016/S1471-4906(01)02060-9.

50. Abel AM, Yang C, Thakar MS, Malarkannan S. Natural killer cells: development, maturation, and clinical utilization. Front Immunol. 2018;9:123. https://doi.org/10.3389/fimmu.2018.01869.

51. Cooper MA, Fehniger TA, Fuchs A, Colonna M, Caligiuri MA. NK cell and DC interactions. Trends Immunol. 2004;25:47-52. https://doi.org/10. 1016/j.it.2003.10.012.

52. Pradier A, Passweg J, Villard J, Kindler V. Human bone marrow stromal cells and skin fibroblasts inhibit natural killer cell proliferation and cytotoxic activity. Cell Transplant. 2011;20:681-91. https://doi.org/10.3727/ 096368910X536545

53. Najar M, Fayyad-Kazan M, Meuleman N, Bron D, Fayyad-Kazan H, Lagneaux L. Mesenchymal stromal cells of the bone marrow and natural killer cells: cell interactions and cross modulation. J Cell Commun Signal. 2018;12:673-88. https://doi.org/10.1007/s12079-018-0448-4.

54. Najar M, Fayyad-Kazan M, Merimi M, Meuleman N, Bron D, FayyadKazan H, Lagneaux L. Reciprocal immuno-biological alterations occur during the co-culture of natural killer cells and adipose tissue-derived 
mesenchymal stromal cells. Cytotechnology. 2019;71:375-88. https:// doi.org/10.1007/s10616-019-00294-6.

55. Najar M, Fayyad-Kazan M, Meuleman N, Bron D, Fayyad-Kazan H, Lagneaux L. Immunological impact of Wharton's Jelly mesenchymal stromal cells and natural killer cell co-culture. Mol Cell Biochem. 2018;447:111-24. https://doi.org/10.1007/s1 1010-018-3297-9.

56. Najar M, Fayyad-Kazan M, Meuleman N, Bron D, Fayyad-Kazan H, Lagneaux L. Immunomodulatory effects of foreskin mesenchymal stromal cells on natural killer cells. J Cell Physiol. 2018;233:5243-54. https://doi. org/10.1002/jcp.26305.

57. Spaggiari GM, Capobianco A, Becchetti S, Mingari MC, Moretta L. Mesenchymal stem cell-natural killer cell interactions: evidence that activated NK cells are capable of killing MSCs, whereas MSCs can inhibit IL-2-induced NK-cell proliferation. Blood. 2006;107:1484-90. https://doi. org/10.1182/blood-2005-07-2775

58. Sotiropoulou PA, Perez SA, Gritzapis AD, Baxevanis CN, Papamichail $\mathrm{M}$. Interactions between human mesenchymal stem cells and natural killer cells. Stem Cells. 2006;24:74-85. https://doi.org/10.1634/stemcells. 2004-0359.

59. Gieseke F, Böhringer J, Bussolari R, Dominici M, Handgretinger R, Müller I. Human multipotent mesenchymal stromal cells use galectin-1 to inhibit immune effector cells. Blood. 2010;116:3770-9. https://doi.org/ 10.1182/blood-2010-02-270777.

60. Li Y, Qu YH, Wu YF, Liu L, Lin XH, Huang K, Wei J. Bone marrow mesenchymal stem cells suppressing activation of allogeneic cytokineinduced killer/natural killer cells either by direct or indirect interaction. Cell Biol Int. 2015;39:435-45. https://doi.org/10.1002/cbin.10404.

61. Guillerey C, Huntington ND, Smyth MJ. Targeting natural killer cells in cancer immunotherapy. Front Pharmacol. 2016;17:1025-36. https://doi. org/10.1038/ni.3518.

62. DelaRosa O, Sánchez-Correa B, Morgado S, Ramírez C, Del Río B, Menta R, Lombardo E, Tarazona R, Casado JG. Human adipose-derived stem cells impair natural killer cell function and exhibit low susceptibility to natural killer-mediated lysis. Stem Cells Dev. 2012;21:1333-43. https:// doi.org/10.1089/scd.2011.0139.

63. Hu CHD, Kosaka Y, Marcus P, Rashedi I, Keating A. Differential immunomodulatory effects of human bone marrow-derived mesenchymal stromal cells on natural killer cells. Stem Cells Dev. 2019;28:933-43. https://doi.org/10.1089/scd.2019.0059.

64. Chatterjee D, Marquardt N, Tufa DM, Hatlapatka T, Hass R, Kasper C, von Kaisenberg C, Schmidt RE, Jacobs R. Human umbilical cord-derived mesenchymal stem cells utilise activin-A to suppress interferon-gamma production by natural killer cells. Front Immunol. 2014;5:1-9. https:// doi.org/10.3389/fimmu.2014.00662.

65. Hosseini E, Ghasemzadeh M, Kamalizad M, Schwarer AP. Ex vivo expansion of CD3depleted cord blood-MNCs in the presence of bone marrow stromal cells; an appropriate strategy to provide functional NK cells applicable for cellular therapy. Stem Cell Res. 2017;19:148-55. https:// doi.org/10.1016/j.scr.2017.01.010.

66. Liu W, Gao Y, Li H, Wang H, Ye M, Jiang G, Chen Y, Liu Y, Kong J, Liu W, Sun M, Hou M, Yu K. Intravenous transplantation of mesenchymal stromal cells has therapeutic effects in a sepsis mouse model through inhibition of septic natural killer cells. Int J Biochem Cell Biol. 2016;79:93-103. https://doi.org/10.1016/j.biocel.2016.08.013.

67. Qingqing $M, X i n Z$, Meizhong S. Bone marrow mesenchymal stem cells altered the immunoregulatory activities of hepatic natural killer cells. Clin Res Hepatol Gastroenterol. 2014;38:689-98. https://doi.org/10. 1016/j.clinre.2014.06.001.

68. Blanco B, Herrero-Sánchez MDC, Rodríguez-Serrano C, García-Martínez ML, Blanco JF, Muntión S, García-Arranz M, Sánchez-Guijo F, del Cañizo C. Immunomodulatory effects of bone marrow versus adipose tissuederived mesenchymal stromal cells on NK cells: implications in the transplantation setting. Eur J Haematol. 2016;97:528-37. https://doi. org/10.1111/ejh.12765.

69. Alter G, Malenfant JM, Altfeld M. CD107a as a functional marker for the identification of natural killer cell activity. J Immunol Methods. 2004;294:15-22. https://doi.org/10.1016/j.jim.2004.08.008.

70. Cohnen A, Chiang SC, Stojanovic A, Schmidt H, Claus M, Saftig P, Janßen O, Cerwenka A, Bryceson YT, Watzl C. Surface CD107a/LAMP-1 protects natural killer cells from degranulation-associated damage. Blood. 2013;122:1411-8. https://doi.org/10.1182/blood-2012-07-441832.
71. Bruno S, Grange C, Tapparo M, Pasquino C, Romagnoli R, Dametto E, Amoroso A, Tetta C, Camussi G. Human liver stem cells suppress T-cell proliferation, NK activity, and dendritic cell differentiation. Stem Cells Int. 2016. https://doi.org/10.1155/2016/8468549.

72. Smyth MJ, Trapani JA. Granzymes: exogenous porteinases that induce target cell apoptosis. Immunol Today. 1995;16:202-6. https://doi.org/10. 1016/0167-5699(95)80122-7.

73. Nagata S, Golstein P. The fas death factor. Science (80-). 1995;267:144956. https://doi.org/10.1126/science.7533326.

74. Van Parijs L, Abbas AK. Role of Fas-mediated cell death in the regulation of immune responses. Curr Opin Immunol. 1996;8:355-61. https://doi. org/10.1016/S0952-7915(96)80125-7.

75. Fu Q, Man X, Yu MIN, Chu Y, Luan X, Piao H, Xue J, Jin C. Human decidua mesenchymal stem cells regulate decidual natural killer cell function via interactions between collagen and leukocyte-associated immunoglobulin—like receptor. Mol Med Rep. 2017;1:2791-8. https://doi. org/10.3892/mmr.2017.6921.

76. Yan F, Liu O, Zhang H, Zhou Y, Zhou D, Zhou Z, He Y, Tang Z, Wang S. Human dental pulp stem cells regulate allogeneic NK cells'function via induction of anti-inflammatory purinergic signalling in activated NK cells. Cell Prolif. 2019;52:1-11. https://doi.org/10.1111/cpr.12595.

77. Radaev S, Sun PD. Structure and function of natural killer cell surface receptors. Annu Rev Biophys Biomol Struct. 2003;32:93-114. https://doi. org/10.1146/annurev.biophys.32.110601.142347.

78. Martinet L, Smyth MJ. Balancing natural killer cell activation through paired receptors. Nat Rev Immunol. 2015;15:243-54. https://doi.org/10. 1038/nri3799.

79. Leung W. Infusions of allogeneic natural killer cells as cancer therapy infusions of allogeneic natural killer cells as cancer therapy CME staff planners' disclosures learning objectives. Clin Cancer Res. 2014;20:3390-400.

80. Carlsten M, Järås M. Natural killer cells in myeloid malignancies: immune surveillance, NK cell dysfunction, and pharmacological opportunities to bolster the endogenous NK cells. Front Immunol. 2019. https://doi.org/10.3389/fimmu.2019.02357.

81. Montaldo E, Del Zotto G, Della Chiesa M, Mingari MC, Moretta A, De Maria A, Moretta L. Human NK cell receptors/markers: a tool to analyze NK cell development, subsets and function. Cytom Part A. 2013;83:70213. https://doi.org/10.1002/cyto.a.22302.

82. Chester C, Fritsch K, Kohrt HE. Natural killer cell immunomodulation: targeting activating, inhibitory, and co-stimulatory receptor signaling for cancer immunotherapy. Front Immunol. 2015. https://doi.org/10. 3389/fimmu.2015.00601.

83. Rahimzadeh A, Mirakabad FST, Movassaghpour A, Shamsasenjan K, Kariminekoo S, Talebi M, Shekari A, Zeighamian V, Ghalhar MG, Akbarzadeh A. Biotechnological and biomedical applications of mesenchymal stem cells as a therapeutic system. Artif Cells Nanomed Biotechnol. 2016:44:559-70. https://doi.org/10.3109/21691401.2014.968823.

84. Abumaree MH, Alshehri NA, Almotery A, Al Subayyil AM, Bahattab E, Abomaray FM, Khatlani T, Kalionis B, Jawdat D, El-Muzaini MF, Al Jumah MA, Alaskar AS. Preconditioning human natural killer cells with chorionic villous mesenchymal stem cells stimulates their expression of inflammatory and anti-tumor molecules. Stem Cell Res Ther. 2019;10:1-15. https://doi.org/10.1186/s13287-019-1153-9.

85. Spaggiari GM, Capobianco A, Abdelrazik H, Becchetti F, Mingari MC Moretta L. Mesenchymal stem cells inhibit natural killer-cell proliferation, cytotoxicity, and cytokine production: role of indoleamine 2,3-dioxygenase and prostaglandin E2. Blood. 2008;111:1327-33. https://doi.org/10.1182/blood-2007-02-074997.

86. Petri RM, Hackel A, Hahnel K, Dumitru CA, Bruderek K, Flohe SB, Paschen A, Lang S, Brandau S. Activated tissue-resident mesenchymal stromal cells regulate natural killer cell immune and tissue-regenerative function. Stem Cell Rep. 2017;9:985-98. https://doi.org/10.1016/j.stemcr. 2017.06.020.

87. Clausen J, Vergeiner B, Enk M, Petzer AL, Gastl G, Gunsilius E. Functional significance of the activation-associated receptors CD25 and CD69 on human NK-cells and NK-like T-cells. Immunobiology. 2003;207:85-93. https://doi.org/10.1078/0171-2985-00219.

88. Galland S, Vuille J, Martin P, Letovanec I, Caignard A, Fregni G, Stamenkovic I. Tumor-derived mesenchymal stem cells use distinct 
mechanisms to block the activity of natural killer cell subsets. Cell Rep. 2017;20:2891-905. https://doi.org/10.1016/j.celrep.2017.08.089.

89. Abumaree MH, Bahattab E, Alsadoun A, Al Dosaimani A, Abomaray FM, Khatlani T, Kalionis B, El-Muzaini MF, Alawad AO, Alaskar AS. Characterization of the interaction between human decidua parietalis mesenchymal stem/stromal cells and natural killer cells. Stem Cell Res Ther. 2018. https://doi.org/10.1186/s13287-018-0844-y.

90. Hoogduijn MJ, Roemeling-Van Rhijn M, Korevaar SS, Engela AU, Weimar W, Baan CC. Immunological aspects of allogeneic and autologous mesenchymal stem cell therapies. Hum Gene Ther. 2011;22:1587-91. https://doi.org/10.1089/hum.2011.039.

91. Liu J, Hu X, Li Z, Yan R, Li D, Wang J, Shan H. In vivo bioluminescence imaging of transplanted mesenchymal stromal cells and their rejection mediated by intrahepatic NK cells. Mol Imaging Biol. 2017;19:3140. https://doi.org/10.1007/s11307-016-0962-9.

92. Kaiserman D, Bird PI. Control of granzymes by serpins. Cell Death Differ. 2010;17:586-95. https://doi.org/10.1038/cdd.2009.169.

93. El Haddad N, Moore R, Heathcote D, Mounayar M, Azzi J, Mfarrej B, Batal I, Ting C, Atkinson M, Sayegh MH, Ashton-Rickardt PG, Abdi R. The novel role of SERPINB9 in cytotoxic protection of human mesenchymal stem cells. J Immunol. 2011;187:2252-60. https://doi.org/10. 4049/jimmunol.1003981.

94. Mangan MSJ, Bird CH, Kaiserman D, Matthews AY, Hitchen C, Steer $\mathrm{DL}$, Thompson PE, Bird PI. A novel serpin regulatory mechanism: SerpinB9 is reversibly inhibited by vicinal disulfide bond formation in the reactive center loop. J Biol Chem. 2016;291:3626-38. https://doi. org/10.1074/jbc.M115.699298.

95. Poggi A GM. IFNGamma priming protects fetal and embryonic MSC from NK cell-mediated killing and improves their immunosuppressive properties: role of activating and inhibitory receptors. J Cell Sci Ther. 2014. https://doi.org/10.4172/2157-7013.1000164.

96. Kariminekoo S, Movassaghpour A, Rahimzadeh A, Talebi M, Shamsasenjan K, Akbarzadeh A. Implications of mesenchymal stem cells in regenerative medicine. Artif Cells Nanomed Biotechnol. 2016;44:74957. https://doi.org/10.3109/21691401.2015.1129620.

97. Polchert D, Sobinsky J, Douglas GW, Kidd M, Moadsiri A, Reina E, Genrich K, Mehrotra S, Setty S, Smith B, Bartholomew A. IFN- $\gamma$ activation of mesenchymal stem cells for treatment and prevention of graft versus host disease. Eur J Immunol. 2008;38:1745-55. https://doi.org/ 10.1002/eji.200738129.

98. Chatterjee D, Marquardt N, Tufa DM, Beauclair G, Low HZ, Hatlapatka T, Hass R, Kasper C, von Kaisenberg C, Schmidt RE, Jacobs R. Role of gamma-secretase in human umbilical-cord derived mesenchymal stem cell mediated suppression of NK cell cytotoxicity. Cell Commun Signal. 2014;12:63. https://doi.org/10.1186/s12964-014-0063-9.

99. Stabile H, Scarno G, Fionda C, Gismondi A, Santoni A, Gadina M, Sciumè G. JAK/STAT signaling in regulation of innate lymphoid cells: the gods before the guardians. Immunol Rev. 2018;286:148-59. https:// doi.org/10.1111/imr.12705.

100. Schindler C, Levy DE, Decker T. JAK-STAT signaling: from interferons to cytokines. J Biol Chem. 2007;282:20059-63. https://doi.org/10. 1074/jbc.R700016200.

101. Villarino AV, Kanno Y, O'Shea JJ. Mechanisms and consequences of Jak-STAT signaling in the immune system. Nat Immunol. 2017;18:374-84. https://doi.org/10.1038/ni.3691.

102. Gotthardt D, Trifinopoulos J, SexI V, Putz EM. JAK/STAT cytokine signaling at the crossroad of NK cell development and maturation. Front Immunol. 2019. https://doi.org/10.3389/fimmu.2019.02590.

103. Levy DE, Darnell JE. STATs: transcriptional control and biological impact. Nat Rev Mol Cell Biol. 2002;3:651-62. https://doi.org/10.1038/ nrm909.

104. Carey A, Tan C, Ulett G. Infection-induced IL-10 and JAK-STAT: a review of the molecular circuitry controlling immune hyperactivity in response to pathogenic microbes. Jak-Stat. 2012;1:159-67. https:// doi.org/10.4161/jkst.19918.

105. Palmer DC, Restifo NP. Suppressors of cytokine signaling (SOCS) in T cell differentiation, maturation, and function. Trends Immunol. 2009;30:592-602. https://doi.org/10.1016/j.it.2009.09.009.

106. Kim WS, Kim MJ, Kim DO, Byun JE, Huy H, Song HY, Park YJ, Kim TD, Yoon SR, Choi EJ, Jung H, Choi I. Suppressor of cytokine signaling 2 negatively regulates NK cell differentiation by inhibiting JAK2 activity. Sci Rep. 2017;7:1-12. https://doi.org/10.1038/srep46153.

107. Allard B, Longhi MS, Robson SC, Stagg J. The ectonucleotidases CD39 and CD73: novel checkpoint inhibitor targets. Immunol Rev. 2017;276:121-44. https://doi.org/10.1111/imr.12528.

108. Cekic C, Linden J. Purinergic regulation of the immune system. Nat Rev Immunol. 2016;16:177-92. https://doi.org/10.1038/nri.2016.4.

109. Blay J, White TD, Hoskin DW. The extracellular fluid of solid carcinomas contains immunosuppressive concentrations of adenosine. Cancer Res. 1997;57:2602-5.

110. Kroemer G, Galluzzi L, Kepp O, Zitvogel L. Immunogenic cell death in cancer therapy. Annu Rev Immunol. 2013;31:51-72. https://doi.org/10. 1146/annurev-immunol-032712-100008.

111. Zhang H, Vijayan D, Li XY, Robson SC, Geetha N, Teng MWL, Smyth MJ. The role of NK cells and CD39 in the immunological control of tumor metastases. Oncoimmunology. 2019;8:1-11. https://doi.org/10.1080/ 2162402X.2019.1593809.

112. Chambers AM, Wang J, Lupo KB, Yu H, Atallah Lanman NM, Matosevic S. Adenosinergic signaling alters natural killer cell functional responses. Front Immunol. 2018;9:2533. https://doi.org/10.3389/fimmu.2018. 02533.

113. Young A, Mittal D, Stagg J, Smyth MJ. Targeting cancer-derived adenosine: new therapeutic approaches. Cancer Discov. 2014;4:879-88, https://doi.org/10.1158/2159-8290.CD-14-0341.

114. Monguió-Tortajada M, Roura S, Gálvez-Montón C, Franquesa M, BayesGenis A, Borràs FE. Mesenchymal stem cells induce expression of CD73 in human monocytes in vitro and in a swine model of myocardial infarction in vivo. Front Immunol. 2017;8:1-13. https://doi.org/10.3389/ fimmu.2017.01577.

115. Meyaard L, Adema GJ, Chang C, Woollatt E, Sutherland GR, Lanier LL, Phillips JH. LAIR-1, a novel inhibitory receptor expressed on human mononuclear leukocytes. Immunity. 1997;7:283-90.

116. Lebbink RJ, De Ruiter T, Adelmeijer J, Brenkman AB, Van Helvoort JM, Koch M, Farndale RW, Lisman T, Sonnenberg A, Lenting PJ, Meyaard L. Collagens are functional, high affinity ligands for the inhibitory immune receptor LAIR-1. J Exp Med. 2006;203:1419-25. https://doi.org/10.1084/ jem.20052554.

117. Lebbink RJ, van den Berg MCW, de Ruiter T, Raynal N, van Roon JAG, Lenting PJ, Jin B, Meyaard L. The soluble leukocyte-associated Ig-like receptor (LAIR)-2 antagonizes the collagen/LAIR-1 inhibitory immune interaction. J Immunol. 2008;180:1662-9. https://doi.org/10.4049/ jimmunol.180.3.1662.

118. Myllyharju J, Kivirikko KI. Collagens, modifying enzymes and their mutations in humans, flies and worms. Trends Genet. 2004;20:33-43. https:// doi.org/10.1016/j.tig.2003.11.004.

119. Lebbink RJ, de Ruiter T, Verbrugge A, Bril WS, Meyaard L. The mouse homologue of the leukocyte-associated Ig-like receptor- 1 is an inhibitory receptor that recruits Src homology region 2-containing protein tyrosine phosphatase (SHP)-2, but not SHP-1. J Immunol. 2004;172:5535-43. https://doi.org/10.4049/jimmunol.172.9.5535.

120. Jan R, Raynal N, De Ruiter T, Bihan DG, Farndale RW, Meyaard L. Identification of multiple potent binding sites for human leukocyte associated Ig-like receptor LAIR on collagens II and III. Matrix Biol. 2009;28:202-10. https://doi.org/10.1016/j.matbio.2009.03.005.

121. Marçais A, Viel S, Grau M, Henry T, Marvel J, Walzer T. Regulation of mouse NK cell development and function by cytokines. Front Immunol. 2013. https://doi.org/10.3389/fimmu.2013.00450.

122. De Sanctis JB, Blanca I, Bianco NE. Secretion of cytokines by natural killer cells primed with interleukin-2 and stimulated with different lipoproteins. Immunology. 1997;90:526-33. https://doi.org/10.1046/j. 1365-2567.1997.00174.x.

123. Cagliani J, Grande D, Molmenti EP, Miller EJ, Rilo HLR. Immunomodulation by mesenchymal stromal cells and their clinical applications. HHS Public Access. 2017.

124. Wong JL, Obermajer N, Odunsi K, Edwards RP, Kalinski P. Synergistic COX2 induction by IFNY and TNFa self-limits type-1 immunity in the human tumor microenvironment. Cancer Immunol Res. 2016;4:303-11. https://doi.org/10.1158/2326-6066.CIR-15-0157.

125. Noronha Nc NDC, Mizukami A, Caliári-Oliveira C, Cominal JG, Rocha JLM, Covas DT, Swiech K, Malmegrim KCR. Priming approaches to 
improve the efficacy of mesenchymal stromal cell-based therapies. Stem Cell Res Ther. 2019. https://doi.org/10.1186/s13287-019-1224-y.

126. Neeb L, Hellen P, Boehnke C, Hoffmann J, Schuh-Hofer S, Dirnagl U, Reuter U. IL-1 $\beta$ stimulates COX-2 dependent PGE2 synthesis and CGRP release in rat trigeminal ganglia cells. PLoS ONE. 2011. https://doi.org/ 10.1371/journal.pone.0017360.

127. Fan H, Zhao G, Liu L, Liu F, Gong W, Liu X, Yang L, Wang J, Hou Y. Pretreatment with IL-1 $\beta$ enhances the efficacy of MSC transplantation in DSS-induced colitis. Cell Mol Immunol. 2012;9:473-81. https://doi.org/ 10.1038/cmi.2012.40.

128. Lee BC, Kim HS, Shin TH, Kang I, Lee JY, Kim JJ, Kang HK, Seo Y, Lee S, Yu KR, Choi SW, Kang KS. PGE 2 maintains self-renewal of human adult stem cells via EP2-mediated autocrine signaling and its production is regulated by cell-to-cell contact. Sci Rep. 2016. https://doi.org/10.1038/ srep26298.

129. Kyurkchiev D. Secretion of immunoregulatory cytokines by mesenchymal stem cells. World J Stem Cells. 2014;6:552. https://doi.org/10.4252/ wisc.v6.15.552.

130. Ling W, Zhang J, Yuan Z, Ren G, Zhang L, Chen X, Rabson AB, Roberts Al, Wang Y, Shi Y. Mesenchymal stem cells use IDO to regulate immunity in tumor microenvironment. Cancer Res. 2014;74:1576-87. https://doi. org/10.1158/0008-5472.CAN-13-1656.

131. Park A, Lee Y, Kim MS, Kang YJ, Park YJ, Jung H, Kim TD, Lee HG, Choi I, Yoon SR. Prostaglandin E2 secreted by thyroid cancer cells contributes to immune escape through the suppression of natural killer (NK) cell cytotoxicity and NK cell differentiation. Front Immunol. 2018. https:// doi.org/10.3389/fimmu.2018.01859.

132. Holt D, Ma X, Kundu N, Fulton A. Prostaglandin E 2 (PGE 2) suppresses natural killer cell function primarily through the PGE 2 receptor EP4. Cancer Immunol Immunother. 2011;60:1577-86. https://doi.org/10. 1007/s00262-011-1064-9.

133. Mizuno R, Kawada K, Sakai Y. Prostaglandin E2/EP signaling in the tumor microenvironment of colorectal cancer. Int J Mol Sci. 2019. https://doi. org/10.3390/ijms20246254.

134. Pietra G, Manzini C, Rivara S, Vitale M, Cantoni C, Petretto A, Balsamo M, Conte R, Benelli R, Minghelli S, Solari N, Gualco M, Queirolo P, Moretta $L$, Mingari MC. Melanoma cells inhibit natural killer cell function by modulating the expression of activating receptors and cytolytic activity. Cancer Res. 2012;72:1407-15. https://doi.org/10.1158/0008-5472. CAN-11-2544.

135. Dupuy S, Lambert M, Zucman D, Choukem SP, Tognarelli S, Pages C, Lebbé C, Caillat-Zucman S. Human herpesvirus 8 (HHV8) sequentially shapes the NK cell repertoire during the course of asymptomatic infection and Kaposi sarcoma. PLoS Pathog. 2012. https://doi.org/10.1371/ journal.ppat.1002486.

136. Harizi H. Reciprocal crosstalk between dendritic cells and natural killer cells under the effects of PGE2 in immunity and immunopathology. Cell Mol Immunol. 2013;10:213-21. https://doi.org/10.1038/cmi.2013.1.

137. Fan C, Tang Y, Wang J, Xiong F, Guo C, Wang Y, Xiang B, Zhou M, Li X, Wu $X$, Li Y, Li X, Li G, Xiong W, Zeng Z. The emerging role of Epstein-Barr virus encoded microRNAs in nasopharyngeal carcinoma. J Cancer. 2018:9:2852-64. https://doi.org/10.7150/jca.25460.

138. Ma OKF, Chan KH. Immunomodulation by mesenchymal stem cells: Interplay between mesenchymal stem cells and regulatory lymphocytes. World J Stem Cells. 2016;8:268-78. https://doi.org/10.4252/wjsc v8.i9.268.

139. Lin A, Yan WH. Heterogeneity of HLA-G expression in cancers: facing the challenges. Front Immunol. 2018;9:2164. https://doi.org/10.3389/ fimmu.2018.02164.

140. Michel T, Poli A, Cuapio A, Iserentant G, Ollert M, Cuapio A, Briquemont B, Michel T, Iserentant G, Ollert M, Zimmer J. Human CD56 bright NK cells: an update. J Immunol. 2016;196:2923-31. https://doi.org/10.4049/ jimmunol.1502570.

141. Delling G, Kaiser E. The origin of the neoplastic stromal cell in giant cell tumor of bone. Hum Pathol. 2003;34:983-93. https://doi.org/10.1053/ S0046-8177(03)00413-1.

142. Johann P, Vaegler M, Gieseke F, Mang P, Armeanu-ebinger S, Kluba T, Handgretinger R, Müller I. Tumour stromal cells derived from paediatric malignancies display MSC-like properties and impair NK cell cytotoxicity. BMC Cancer. 2010;10:1-10.
143. Hontscha C, Borck Y, Zhou H, Messmer D. Clinical trials on CIK cells: first report of the international registry on CIK cells (IRCC). J Cancer Res Clin Oncol. 2011;137:305-10. https://doi.org/10.1007/s00432-010-0887-7.

144. Li Y, Qu Y, Wu Y, Wang X. Bone marrow mesenchymal stem cells reduce the antitumor activity of cytokine-induced killer/natural killer cells in K562 NOD/SCID mice. Ann Hematol. 2011;90:873-85. https://doi.org/ 10.1007/s00277-011-1156-9.

145. Entrena A, Varas A, Vázquez M, Melen GJ, Fernández-Sevilla LM, GarcíaCastro J, Ramírez M, Zapata AG, Vicente Á. Mesenchymal stem cells derived from low risk acute lymphoblastic leukemia patients. Cancer Lett. 2015;363:156-65. https://doi.org/10.1016/j.canlet.2015.04.012.

146. Mandal A, Viswanathan C. Natural killer cells: in health and disease. Hematol Oncol Stem Cell Ther. 2015;8:47-55. https://doi.org/10.1016/j. hemonc.2014.11.006.

147. Jira M, Antosova E, Vondra V, Strejcek J, Mazakova H, Prazakova J. Natura killer and interleukin-2 induced cytotoxicity in asthmatics: I. Effect of acute antigen-specific challenge. Allergy. 1988;43:294-8. https://doi. org/10.1111/j.1398-9995.1988.tb00903.x.

148. Culley FJ. Natural killer cells in infection and inflammation of the lung. Immunology. 2009;128:151-63. https://doi.org/10.1111/j.1365-2567. 2009.03167.x

149. Wingett $D$, Nielson CP. Divergence in NK cell and cyclic AMP regulation of T cell CD40L expression in asthmatic subjects. J Leukoc Biol. 2003;74:531-41. https://doi.org/10.1189/jlb.0303103.1.

150. Ple C, Barrier M, Amniai L, Marquillies P, Bertout J, Tsicopoulos A, Walzer T, Lassalle P, Duez C. Natural killer cells accumulate in lung-draining lymph nodes and regulate airway eosinophilia in a murine model of asthma. Scand J Immunol. 2010;72:118-27. https://doi.org/10.1111/j. 1365-3083.2010.02419.x.

151. Poggi A, Zocchi MR. NK cell autoreactivity and autoimmune diseases. Front Immunol. 2014. https://doi.org/10.3389/fimmu.2014.00027.

152. Benczur M, Petrányl GG, Pálffy G, Varga M, Tálas M, Kotsy B, Földes I, Hollán SR. Dysfunction of natural killer cells in multiple sclerosis: a possible pathogenetic factor. Clin Exp Immunol. 1980;39:657-62.

153. Braakman E, van Tunen A, Meager A, Lucas CJ. Natural cytotoxic activity in multiple sclerosis patients: defects in IL-2/interferon gamma-regulatory circuit. Clin Exp Immunol. 1986;66:285-28594.

154. Gur C, Porgador A, Elboim M, Gazit R, Mizrahi S, Stern-Ginossar N, Achdout H, Ghadially H, Dor Y, Nir T, Doviner V, Hershkovitz O, Mendelson M, Naparstek Y, Mandelboim O. The activating receptor NKp46 is essential for the development of type 1 diabetes. Nat Immunol. 2010;11:121-8. https://doi.org/10.1038/ni.1834.

155. Pazmany L. Do NK cells regulate human autoimmunity? Cytokine. 2005;32:76-80. https://doi.org/10.1016/j.cyto.2005.07.013.

156. Dalbeth N, Callan MFC. A subset of natural killer cells is greatly expanded within inflamed joints. Arthritis Rheum. 2002;46:1763-72. https://doi.org/10.1002/art.10410.

157. Hervier B, Beziat V, Haroche J, Mathian A, Lebon P, Ghillani-Dalbin $P$, Musset L, Debré P, Amoura Z, Vieillard V. Phenotype and function of natural killer cells in systemic lupus erythematosus: excess interferon- $\gamma$ production in patients with active disease. Arthritis Rheum. 2011;63:1698-706. https://doi.org/10.1002/art.30313.

158. Schepis D, Gunnarsson I, Eloranta ML, Lampa J, Jacobson SH, Kärre K, Berg L. Increased proportion of CD56bright natural killer cells in active and inactive systemic lupus erythematosus. Immunology. 2009;126:140-6. https://doi.org/10.1111/j.1365-2567.2008.02887.x.

159. Paust $\mathrm{S}$, Senman B. Adaptive immune responses mediated by natural killer cells. Immunol Rev. 2010;235:286-96.

160. Moloudizargari M, Govahi A, Fallah M. The mechanisms of cellular crosstalk between mesenchymal stem cells and natural killer cells: therapeutic implications. J Cell Physiol. 2020. https://doi.org/10.1002/ jcp.30038.

161. Wu X, Jiang J, Gu Z, Zhang J, Chen Y, Liu X. Mesenchymal stromal cell therapies: immunomodulatory properties and clinical progress. Stem Cell Res Ther. 2020;11:1-6.

162. De Becker A, Van Riet I. Homing and migration of mesenchymal stromal cells: How to improve the efficacy of cell therapy? World J Stem Cells. 2016;8:73-87. https://doi.org/10.4252/wjsc.v8.i3.73.

163. Benichou G, Yamada Y, Aoyama A, Madsen JC. Natural killer cells in rejection and tolerance of solid organ allografts. Curr Opin Organ Transplant. 2011;16:47-53. https://doi.org/10.1097/MOT.0b013e32834254cf. 
164. Hamerman JA, Ogasawara K, Lanier LL. NK cells in innate immunity. Curr Opin Immunol. 2005;17:29-35. https://doi.org/10.1016/j.coi.2004. 11.001.

165. Lanier LL. NK cell recognition. Annu Rev Immunol. 2005;23:225-74. https://doi.org/10.1146/annurev.immunol.23.021704.115526.

166. Calne RY, Rolles K, White DJG, Thiru S. Cyclosporin A initially as the only Immunosppressant in 34 recipients of cadaveric organs. Lancet. 1979;314:1033-6.

167. Ascha MS, Ascha ML, Hanouneh IA. Management of immunosuppressant agents following liver transplantation: less is more. World J Hepatol. 2016;8:148-61. https://doi.org/10.4254/wjh.v8.i3.148.

168. Ej Reinders M. NK cells and MSCs: possible implications for MSC therapy in renal transplantation. J Stem Cell Res Ther. 2014. https://doi.org/10. 4172/2157-7633.1000166.

169. Salem HK, Thiemermann C. Mesenchymal stromal cells: current understanding and clinical status. Stem Cells. 2010;28:585-96. https://doi.org/ 10.1002/stem.269

170. Ben Nasr M, Vergani A, Avruch J, Liu L, Kefaloyianni E, D’Addio F, Tezza S, Corradi D, Bassi R, Valderrama-Vasquez A, Usuelli V, Kim J, Azzi J, El Essawy B, Markmann J, Abdi R, Fiorina P. Co-transplantation of autologous MSCs delays islet allograft rejection and generates a local immunoprivileged site. Acta Diabetol. 2015;52:917-27. https://doi.org/ 10.1007/s00592-015-0735-y.

171. Le Blanc K, Ringde O. Immunomodulation by mesenchymal stem cells and clinical experience. J Intern Med. 2007;262:509-25. https://doi.org/ 10.1111/j.1365-2796.2007.01844.x.

172. Crop MJ, Baan CC, Korevaar SS, Ijzermans JNM, Alwayn IPJ, Weimar W, Hoogduijn MJ. Donor-derived mesenchymal stem cells suppress alloreactivity of kidney transplant patients. Transplantation. 2009;87:896-906. https://doi.org/10.1097/TP.0b013e31819b3d72.

173. Huang WH, Chen HL, Huang PH, Yew TL, Lin MW, Lin SJ, Hung SC. Hypoxic mesenchymal stem cells engraft and ameliorate limb ischaemia in allogeneic recipients. Cardiovasc Res. 2014;101:266-76. https:// doi.org/10.1093/cvr/cvt250

174. Ishida N, Ishiyama K, Saeki Y, Tanaka Y. Cotransplantation of preactivated mesenchymal stem cells improves intraportal engraftment of islets by inhibiting liver natural killer cells in mice. Am J Transplant. 2019;19:2732-45. https://doi.org/10.1111/ajt.15347.

\section{Publisher's Note}

Springer Nature remains neutral with regard to jurisdictional claims in published maps and institutional affiliations.

Ready to submit your research? Choose BMC and benefit from:

- fast, convenient online submission

- thorough peer review by experienced researchers in your field

- rapid publication on acceptance

- support for research data, including large and complex data types

- gold Open Access which fosters wider collaboration and increased citations

- maximum visibility for your research: over $100 \mathrm{M}$ website views per year

At BMC, research is always in progress.

Learn more biomedcentral.com/submissions 